\title{
Relational governance, organizational unlearning and learning: implications for performance
}

\author{
Volkan Yeniaras \\ Department of Business Administration, Ozyegin University, Istanbul, Turkey \\ Anthony Di Benedetto \\ Department of Marketing and Supply Chain Management, Temple University, Philadelphia, Pennsylvania, USA \\ Ilker Kaya \\ School of Business and Management, American University of Sharjah, Sharjah, United Arab Emirates, and \\ Mumin Dayan \\ United Arab Emirates University, Al Ain, United Arab Emirates
}

\begin{abstract}
Purpose - Drawing on the literature on dynamic skills, this study builds upon and empirically tests a conceptual model that connects business and political ties, organizational unlearning, organizational learning and firm performance. Specifically, this study suggests that business ties enable and political ties inhibit organizational unlearning (i.e. regenerative dynamic capability), which may, in turn, affect exploratory (i.e. renewing dynamic capability) and exploitative (i.e. incremental dynamic capability) innovation behaviors of the firm. Thus, the purpose of this study is to offer a theoretical framework in which organizational unlearning and learning act as mediating mechanisms between business and political ties and firm performance.

Design/methodology/approach - Structural equation modeling and mediation analyzes were used on a sample of 302 small and medium-size enterprises in Turkey.

Findings - This study found that business ties enable organizational unlearning while political ties impede it. This study further demonstrates that business ties positively and political ties negatively relate to organizational learning through organizational unlearning. In addition, this study shows that political ties are mostly negatively and indirectly related to firm performance through organizational learning while business ties positively and indirectly relate to firm performance.

Practical implications - The findings demonstrate the critical role that personal networks play in organizational learning and firm performance. This study provides evidence to the need to recognize and evaluate the potential and undesirable impacts of political ties on cultivating innovation skills and firm performance. In addition, this study recommends managers to embrace the significance of organizational unlearning in strategic renewal, particularly as it applies to building renewing and incremental dynamic skills for enhanced firm performance.

Originality/value - This study offers a deeper perspective of the dissected relations of social ties in emerging economies to firm performance by considering organizational unlearning and learning behaviors as mediating mechanisms.
\end{abstract}

Keywords Organizational learning, Political ties, Dynamic capabilities, Firm performance, Business ties, Organizational unlearning

Paper type Research paper

\section{Introduction}

Organizational learning emerged as a research theme in various domains ranging from strategy (Levinthal and March, 1993; Vera and Crossan, 2004; Yeniaras et al., 2020) to entrepreneurship (Kollmann and Stöckmann, 2014; Yeniaras et al., 2017) and product innovation (Jin et al., 2016; Piao and Zajac, 2016). Exploitative and exploratory innovation lie at the very core of commercial processes that ensure a firm's current

The current issue and full text archive of this journal is available on Emerald Insight at: https://www.emerald.com/insight/0885-8624.htm

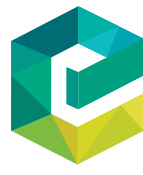

Journal of Business \& Industrial Marketing 36/3 (2021) 469-492

(C) Emerald Publishing Limited [ISSN 0885-8624] [DOI 10.1108/JBIM-01-2020-0002] and future viability (Yalcinkaya et al., 2007) and economic growth in general (Sørensen and Stuart, 2000). Given today's highly turbulent and dynamic markets, ongoing innovation and the ability to renew information are indispensable to improving a firm's performance against that of its competitors (Sanz-Valle et al., 2011). In such competitive and vibrant markets, the products and services offered by companies, as well as the information used to produce them, may quickly become

Funding: This work was supported by the American University of Sharjah [grant number EFRG18-AAB-SBA-80)].

Received 3 January 2020

Revised 25 February 2020

18 April 2020

1 July 2020

8 July 2020

Accepted 9 July 2020 
outdated (Yeniaras and Unver, 2016). Nevertheless, the extant literature typically overlooks the fact that firms accumulate knowledge in their procedures, standards, rules and methods, which are accrued over time (March, 1991). Efficient and effective organizational learning, as it relates to product innovation, may not materialize without unlearning accumulated knowledge, behaviors, beliefs and processes (Becker, 2010; Starbuck, 1996). Several scholars suggest that unlearning is a deliberate, voluntary effort (Tsang and Zahra, 2008; Cegarra-Navarro et al., 2013; de Holan and Phillips, 2011) that discards obsolete information, standards and procedures. By following this premise, we propose that organizational unlearning (as a regenerative dynamic capability) allows firms to move away from established processes and routines toward new, dynamic capabilities, which enable them to develop and use their innovation competence to achieve a sustainable, competitive advantage and superior performance.

As organizations are open systems and do not solely have an internal focus in strategic renewal (Crossan et al., 1999), organizational learning occurs at the individual or group level but may also comprise the use of relational governance mechanisms outside of the firm's boundaries (Dyer and Singh, 1998). Subscribing to a collectivistic approach, we believe that social capital is heterogeneously distributed across organizations and it is the individuals that act and make decisions (Felin and Hesterly, 2007), which, in turn, produce strategic phenomena (Abell et al., 2008). The current literature identifies managerial informal social ties, which is an informal type of individual social capital, as sources of organizational learning (Adler and Kwon, 2002; Janssen et al., 2006). However, these studies have not thoroughly examined the dissected relationships among the types of relational governance mechanisms (i.e. business and political ties) on organizational learning (Atuahene-Gima and Murray, 2007). Managerial informal social connections, such as business and political ties, link managers with external networks ( $\mathrm{Li}$ et al., 2009; Zhou and Poppo, 2010) and also enable firms to obtain (relational) economic rents that would not otherwise be possible (Dyer and Singh, 1998). These rents include give-andtake of market information and expertise (Ang, 2008), joint use of capabilities (Hagedoorn and Frankort, 2008) in business ties and low-interest loans, grants, subsidies and tax-cuts (Goldman et al., 2013), market legitimacy and insider information (Ang, 2008) in political ties. These relational rents may relax resource scarcity spanning resource allocation in organizational learning processes. Nevertheless, managerial social relationships also carry risks that may at times outweigh their benefits (Forkmann et al., 2018; Gao et al., 2017). In emerging economies, managers foster relationships not only with suppliers, distributors, customers, collaborators and competitors (i.e. business ties) but also with political actors (i.e. political connections) (Sheng et al., 2011). Managerial informal social ties, which firms rely on in emerging economies for external resources, may impede organizational learning because of their bittersweet nature (Gao et al., 2017), though this effect has not been tested in depth. For example, political relationships create complacency (Gao et al., 2017) and inflexibility (Chung et al., 2016) within firms, which may make it difficult for organizations to abandon their old ways. While learning is documented as an advantage of social capital in general (Adler and Kwon, 2002), few studies have explored the influences of managerial informal social ties on organizational learning (Atuahene-Gima and Murray, 2007). Furthermore, organizational unlearning as a mediating mechanism in the relationship between organizational learning and managerial informal social connections has been understudied.

Based on the above considerations, our research questions can be summarized as follows:

RQ1. What are the distinct effects of business and political ties on organizational unlearning (i.e., regenerative dynamic capability)?

RQ2. How do business and political ties affect exploitative and exploratory innovation (i.e., renewing and incremental dynamic competencies), and ultimately, firm performance?

We develop a conceptual model containing hypotheses to address our research questions. We empirically test our hypotheses using survey data of small and medium-sized enterprises (SME) located in Turkey for three reasons. First, the organizational unlearning literature pertinent to the investigation of its antecedents and consequences has left emerging economies relatively unexplored (Johnson and Tellis, 2008; Yeniaras et al., 2020). Second, and relatedly, firms in emerging economies have limited access to credit and equity capital both internally and externally compared to their counterparts in developed economies. In addition, according to a 2018 review of European Commission, there are 9.960 million employees working at a total of 2.67 million SMEs with an average number of employees of only 4 . In light of such market inadequacies and limited internal capital (including internal social capital and managerial experience) (Menguc et al., 2020) firms essentially rely on external capital (Yildirim et al., 2013) and resources that they generate through managerial social (business and political) connections (Zhang et al., 2015; Zhou and Poppo, 2010). Third, organizational outcomes of managerial social ties are scrutinized in samples typically limited to East Asian markets (Sheng et al., 2011; Zhang et al., 2015). Turkey is an ideal emerging economy within which to conduct this research. From March 1999 to December 2018, with an average gross domestic product growth rate of $6.2 \%$, Turkey has been a significant actor in the international economy, and Turkish companies are eager to become global successes. Organizational unlearning and innovation capabilities may help firms to overcome the dynamic and turbulent nature of emerging markets. The Turkish market setting could provide robust results in analyzing the links between managerial social ties, organizational unlearning, innovation capabilities and performance outcomes.

This study makes three noteworthy contributions to contemporary research. First, following the previous and current literature, we establish organizational unlearning as an intentional, fundamental process of learning that supports innovation skills (e.g. exploitation and exploration) for generating economic value, as well as securing a competitive position and achieving superior performance in dynamic and 
turbulent environments (Akgün et al., 2007; Zahra et al., 2011; Leal-Rodríguez et al., 2015). To this end, to the best of our knowledge, no prior study has looked at the relationship between business and political ties and organizational unlearning regarding firms' innovation capacity and performance outcomes. Second, empirical studies on the links between managerial social ties and firm performance in emerging economies have provided mixed results. While some cannot conclude significant associations (Lau et al., 2002), others propose that managerial social ties enhance financial outcomes (Luo and Chen, 1997) and firm performance (Li et al., 2008; Sheng et al., 2011). More recent studies suggest that political ties may only be indirectly related to firm performance through mediating mechanisms such as strategy formation and/or innovation behavior (Yeniaras et al., 2020). We suggest that organizational unlearning and innovation capabilities will explain the relationship between business and political ties and firm performance (i.e. customer capital, as well as strategic and financial performance). Third, we enrich the mostly theoretical propositions regarding the antecedents and consequences of organizational unlearning (Hedberg, 1981; Starbuck, 1996; Becker, 2008, 2010; Casillas et al., 2010; Akgün et al., 2007; de Holan and Phillips, 2011; Becker, 2008; Cegarra-Navarro and Cepeda-Carrión, 2013) by providing empirical evidence via data collected from Turkish SMEs.

\section{Theoretical framework}

We provide the theoretical framework for our study in Figure 1.

\subsection{Organizational unlearning and dynamic capabilities} Today's markets have become increasingly dynamic environments with technological, economic and political turbulence (Schmitt et al., 2018); this requires organizations to exploit their existing skills and build new competencies (Raisch and Birkinshaw, 2008) to ascertain long-term superior and sustainable performance (Lechner and Floyd, 2012). The literature pertinent to organizational strategy identifies this adaptive and dynamic process as strategic renewal (Schmitt et al., 2016). The extant literature highlights organizational learning as a principal component of strategic renewal (Crossan et al., 1999; Crossan and Berdrow, 2003; Salvato, 2009). In other words, for firms to respond to increasing global competition, shorter product lifecycles and increased rates at which technological advances occur, they need to harness what they have previously learned while exploring and learning new methods (March, 1991). Exploitation involves using current capabilities as part of the strategic renewal process in terms of gradually altering existing resource configurations (Stopford and Baden-Fuller, 1994); this leads to strategic adaptations to the organization's business model (Huff et al., 1992). Exploration refers to discontinuous renewal procedures (Agarwal and Helfat, 2009), which translate into the

Figure 1 Conceptual framework

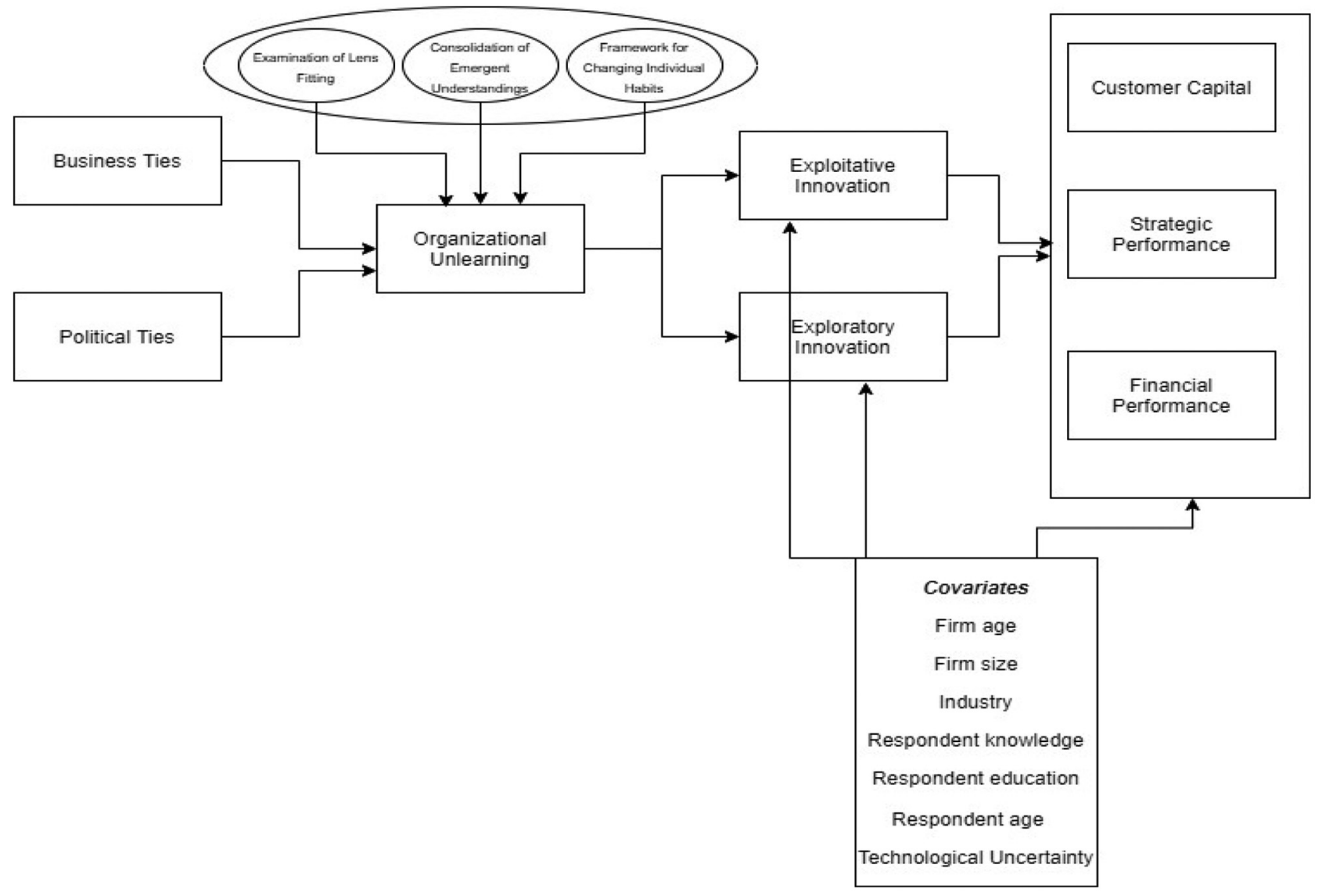


acceptance of new business models at the organizational level (Huff et al., 1992). Nevertheless, while both forms of organizational learning are quintessential for sustainable competitive advantage, they compete for scarce resources that are available to a firm. Accordingly, finding the right balance between exploitation and exploration is of critical importance (De Geus, 1988; March, 1991).

The dynamic capability framework, which is derived from the resource-based view of a firm, chiefly scrutinizes how organizations discern a competitive advantage by reconfiguring their internal and external resource bundles as sources of competitive advantage (Abraham et al., 2012; Teece, 2007). Specifically, in this study, we draw upon a more recent definition of dynamic skills as proposed by Helfat et al. (2007), and conceptualize them as the organization's ability to purposefully create, extend or modify its resource base. Such dynamic competencies that are built over long periods of time (Ambrosini and Bowman, 2009) involve organizational processes and routines, which may have become embedded in the organization (Zollo and Winter, 2002) and might need to be refreshed (Winter, 2003) to minimize competitive pressures (Ambrosini and Bowman, 2009; Teece, 2007; Vera et al., 2016). Eisenhardt and Martin's (2000) proposition suggests that dynamic capabilities may also be useful in stable environments and breaks them down into two levels: incremental dynamic and renewing dynamic capacities (Ambrosini and Bowman, 2009). Dynamic skills do not solely develop in fast changing environments but also come about in relatively stable settings in the form of incremental, continuous improvement of existing resource bases. Such dynamic capabilities are labeled incremental (Ambrosini and Bowman, 2009; Helfat and Peteraf, 2003) and relate to the gradual modification of current resource configurations (Stopford and Baden-Fuller, 1994) (i.e. exploitative innovation). Such capabilities primarily relate to capitalizing on the present set of skills and competencies (March, 1991). Units and organizations that pursue exploitative innovation extend existing products and services for existing customers (Benner and Tushman, 2003) by building on the current knowledge bases and strengthening internal skills, processes and structures (Benner and Tushman, 2002; Levinthal and March, 1993).

The second level of dynamic capabilities (i.e. renewing) refers to purposefully renewing the nature of the organizational resource stock. In contrast to incremental dynamic competencies, with renewing dynamic skills, new resources need to be created, introduced or reconfigured in a completely different way (Ambrosini and Bowman, 2009). Exploratory innovation capability, which refers to discontinuous renewal procedures and the adoption of new business models at the organizational level (Huff et al., 1992), implies renewing dynamic capabilities. While both incremental and renewing dynamic capabilities require an organization to change its resource base, the former entail its adjustment and incremental refinement, and the latter require the firm to purposefully create, extend or modify it (Helfat et al., 2007).

According to Ambrosini and Bowman (2009), the third level of dynamic capabilities, namely, regenerative dynamic capacities, are needed not to alter an organization's resource base, but to modify its current set of dynamic skills. Regenerative dynamic capabilities enable a firm to move away from previous routines, processes and practices toward new dynamic abilities that are critical for firm survival, especially in unstable environments (Gilbert, 2005). In the same vein, organizational unlearning may serve to disrupt the existing way of thinking and to find new spaces within the market. Alternately, complexity theory (Anderson, 1999) may also be useful to provide a theoretical background. The chief purpose of regenerative dynamic competencies is to either embed new dynamic capabilities or improve existing ones (Ambrosini and Bowman, 2009). The presence (or lack) of regenerative skills may be the explanatory factor between firms that prevail or fail (Danneels, 2002).

Accordingly, we label organizational unlearning - which refers to a firm's ability to abandon outdated practices and routines, which precedes organizational learning (i.e. exploratory and exploitative innovation) (Zhao et al., 2013) - as the third level of dynamic capabilities; that is, regenerative dynamic capacities. Thus, in this study, instead of adopting a static capability approach, we conceptualize organizational unlearning as a dynamic capability.

\subsection{Theory and development of the hypotheses}

Organizational learning is a principal mean of successful strategic renewal in an enterprise (Crossan et al., 1999) and is theorized as a continuum that ranges from exploration to exploitation (March, 1991). Strategic renewal requires a simultaneous approach to exploring and learning new ways, methods and processes (March, 1991) while gradually modifying the existing resource configurations (Stopford and Baden-Fuller, 1994). Consequently, exploration and exploitation that add to an organization's ability to identify and capitalize on market opportunities (Hooley et al., 1992) are forms of organizational learning (Wang and Ahmed, 2007; Crossan et al., 1999). Exploratory innovation, as an incremental dynamic skill, involves radical innovations designed to meet the emerging needs of customers or markets (Benner and Tushman, 2003). Exploratory innovation, as a renewing dynamic competency, offers new product/service designs, creates new markets, develops fresh distribution channels (Abernathy and Clark, 1985), and requires acquiring contemporary knowledge or abandoning the accepted understanding (Levinthal and March, 1993). While exploitative innovation consists of incremental changes (Benner and Tushman, 2003) that necessitate enhancing current know-how, skills, procedures and configurations (Levinthal and March, 1993; Abernathy and Clark, 1985), exploratory innovation involves challenging existing ideas that are predominant within an organization (Levinthal and March, 1981). Accordingly, organizations that engage in exploitative innovation need to reinforce their operational efficiency (Porter, 1996) through activities related to refinement, efficiency, implementation, production and execution (March, 1991).

Consequently, organizational unlearning not only precedes renewing dynamic capabilities where new competencies are acquired but also incremental dynamic skills as well, as developing the latter (i.e. exploitative innovation) requires recognizing and unlearning old procedures and mental models that are no longer efficient or effective (Tsang and Zahra, 2008). 
In the organizational learning literature, unlearning has been examined from two separate angles: intentional and unintentional unlearning (Cegarra-Navarro et al., 2016). Unintentional unlearning refers to the accidental loss of knowledge, skills and competencies, while intentional unlearning is the purposeful disruption of well-established organizational routines (Zahra et al., 2011). Such routines entail repetitive patterns of interdependent actions that create path dependencies (Swift and Hwang, 2008), which, in turn, may threaten a firm's survival (Collinson and Wilson, 2006). While the organizational unlearning literature (CegarraNavarro and Sánchez-Polo, 2008) generally assumes that organizational unlearning stems from individual and grouplevel unlearning (Ceggarra-Navarro and Moya, 2005), organizations are more than simply a pool or group of individuals.

(Un)learning is rooted in an organization's systems, structures, routines, information systems and strategies (Crossan et al., 1999). Organizational learning is a dynamic process that occurs at the individual, group and organizational levels. Accordingly, new learning not only flows from the individual to the group and to the organization but also from the organization down to the individual as established behaviors, values, norms and other fundamental assumptions may no longer fit the context. That is, (un)learning - which is critical to respond to environmental changes and meet market and customer demands - takes time (Crossan et al., 1999). Hence, organizations with greater unlearning abilities may achieve superior, sustainable performance in the long term (Lechner and Floyd, 2012) and strategic renewal (Cummings and Teng, 2003). Organizational unlearning includes leaving behind obsolete routines, in addition to discarding outdated organizational knowledge (Hedberg, 1981; Tsang and Zahra, 2008; Zhao et al., 2013). In addition, organizational unlearning helps firms to reconfigure and efficiently distribute their scarce internal resources and enriches their scope while minimizing the cost and time of switching between them (Wang et al., 2019), thereby facilitating organizational learning. In the same vein, drawing from the evolutionary theory of organizational competencies (Hunt, 1997), the extant literature implies that organizational unlearning should come before organizational learning (Tsang and Zahra, 2008), as the first phase of learning is to challenge habits and behaviors that have worked well in the past (McGill and Slocum, 1993). Consequently, replacing tested behaviors and habits is vital to developing the ability to create new products and services (Cepeda-Carrión et al., 2012). In this study, drawing from the dynamic capabilities framework, we conceptualize organizational unlearning as a generative dynamic capability that helps to develop exploitative and exploratory innovation skills as incremental and renewing dynamic capabilities, respectively.

In emerging markets, firms mostly suffer from resource scarcity, as well as limited access to credit and other resource markets due to underdeveloped markets and weak institutions (Kaya and Kaya, 2019; Yildirim et al., 2013). Relational governance theory suggests that firms can expand their resource bases through managerial informal relations with both market (i.e. business ties) and political actors (i.e. political ties) (Morgan and Hunt, 1994; Sheng et al., 2011). Acquiring new expertise and resources is a necessary condition of organizational learning (Benner and Tushman, 2003; Danneels, 2002). Thus, an organization's networks and connections (i.e. network position, network density, technological distance, collaboration and network distance) which expand a firm's resource bases - have emerged as phenomena of interest in the marketing management literature (Wang et al., 2014; Gilsing et al., 2008). Some prior studies identify relational governance mechanisms as antecedents of organizational learning (Dyer and Singh, 1998), but few have scrutinized the dissected relationships between business and political ties and organizational learning as it relates to exploratory and exploitative innovation (Jansen et al., 2006; Su and Yang, 2018; Yeniaras et al., 2020). Unlike contractual relationships in which relational governance is bound by contractual agreements (Poppo and Zenger, 2002; Macneil, 1980), managerial social ties establish shared values and agreed-on processes, which send a signal of trust (Bernheim and Whinston, 1998). This prevents the parties in a social exchange from engaging in opportunistic behavior that may be observed in contractual relationships (Ghoshal and Moran, 1996). Nevertheless, business and political links are not free of disadvantages and could hamper organizational (un)learning capabilities (Forkmann et al., 2018; Gao et al., 2017). Thus, drawing from relational governance theory and the dynamic capabilities framework, we do not only investigate the dissected relationships between business and political ties and organizational unlearning and learning; but we also look at (financial and non-financial) performance implications, as illustrated in Figure 1.

\subsubsection{Business and political ties and organizational unlearning}

Organizations accrue knowledge overtime in their norms, processes, policies and methods (March, 1991). Promoting organizational learning - the ability to learn quicker than other competing firms in the market - may be the only way of developing ground-breaking and cutting-edge goods, services and processes for firms (Senge, 1990). Ongoing innovation and the ability to update old skills are indispensable to boosting a firm's performance against that of its competitors (Sanz-Valle et al., 2011). However, organizational learning itself might not be the minimum requirement to develop and cultivate incremental (i.e. exploitative) and renewing (i.e. exploratory) dynamic skills. This is because firms that operate in emerging economies have limited access to internal equity capital (Schiffer and Weder, 2001). To circumvent the problem of limited access to internal and external equity capital, SMEs in emerging economies often resort to managerial informal relationships to obtain equity (i.e. business and political ties) (Sheng et al., 2011). In addition, in accordance with the literature (Hedberg, 1981; Tsang and Zahra, 2008; Zhao et al., 2013), we argue that limited access to resources forces firms to unlearn established methods and procedures to efficiently reconfigure and distribute their scarce internal resources while enriching their scope (Wang et al., 2013); this facilitates organizational learning (i.e. exploratory and exploitative innovation competencies) (Cepeda-Carrión et al., 2012). Thus, drawing upon the dynamic capabilities framework, we suggest that organizations with regenerative dynamic capabilities (i.e. organizational unlearning) could be better at developing such incremental and renewing dynamic capacities. 
Organizational unlearning is a three-dimensional phenomenon:

1 The examination of lens fitting proposes a perception shift and interrupts an organization's customary, comfortable status quo to foster awareness of new views. This requires an organization to identify obsolete perceptions.

2 The consolidation of emergent beliefs implicates procedures inside organizations that permit personnel to build and use problem-solving skills, so that instead of only following directions, individuals can critically assess problems. Personnel are able to apply their skills by using new conceptual models built on adapting to new knowledge assemblies.

3 The framework for changing individual habits relates to a firm's efforts to eliminate incorrect, inappropriate customs and standards or manners before developing ideas or changes regarding the firm's procedures (Cegarra-Navarro and Sánchez-Polo, 2008; CegarraNavarro et al., 2011).

The relational governance perspective pinpoints two distinct managerial informal social ties: business and political connections. Such relationships span informal managerial ties not only with business partners (e.g. suppliers, competitors, customers, other market collaborators) but also with government officials and entities (e.g. political officials at tax bureaus, state banks, commercial administration bureaus) (Poppo and Zenger, 2002). Business ties refer to a firm's informal social links with suppliers, competitors, customers and other market collaborators (Sheng et al., 2011); they facilitate the exchange of expertise and information between collaborating partners (Ang, 2008), as well as the joint use of capabilities and resources (Hagedoorn and Frankort, 2008). In addition to intellectual benefits that contain complementary or new information, which broadens the complexity and scope of organizational knowledge ( $\mathrm{Li}$ and Sheng, 2011), business relationships also enable access to wide-ranging and timely market information (Peng and Luo, 2000). Access to contemporary, heterogeneous know-how (Rodan and Galunic, 2004) acquired though such ties offers a superior range of perspectives and guidance for problem-solving (Gibbons, 2004; Sparrowe and Liden, 2005). The ability to recognize shifts in the market is associated with a firm's capacity to abandon outdated practices and routines, as well as to discard obsolete or misleading organizational knowledge, and consequently adjust (i.e. deviate from) its strategic actions (Lant et al., 1992). By providing managers and organizations with a greater awareness concerning prospects and changes, business connections allow managers and organizations to create new (or alter the combination of) resources, which enables a firm to fine-tune their resource allocations (Fernández-Pérez et al., 2013).

Political ties entail managerial links with government officials at different levels of public administration such as tax bureaus, state banks and commercial agencies (Li and Zhang, 2007; Peng and Luo, 2000; Xin and Pearce, 1996). Such connections may offer tangible benefits such as low-interest loans, tax cuts, grants and subsidies and government contracts and licenses (Goldman et al., 2013) and/or intangible benefits such as legitimacy, persuading procedures and regulations, easing and enabling market access and the flow of insider information about potential new government regulations (Ang, 2008). Furthermore, information gained through political ties will typically be delayed and does not provide product or segmentbased information (Glazer and Weiss, 1993). Finally, and importantly, the formation of bureaucratic structures is hierarchical where the superordinate players have authority over subordinates. Consequently, strong political ties may convert the organizational culture into a more hierarchical, rigid scheme that could impede inter-departmental synchronization and information sharing (Chung et al., 2016). Such environments can weaken a firm's capacity to adopt new standards and procedures, and lead it to deviate from previously developed practices and routines (Chung, 2011). Considering all the negative aspects of political ties, one may question the rationale behind investing initial resources into cultivating such relations. Recently, in Turkey, as in many emerging and transitional economies, political ties appear to become more important for firms (Alimadadi and Pahlberg, 2014; Özcan and Gündüz, 2015). In emerging economies, as opposed to in developed countries, political connectedness has almost become a necessity as the current political climate strives to foster a new class of stakeholders in power (Atasoy, 2009). Accordingly, firm survival in such economies do not only depend on the breadth of their market-based relationships but also on their political ties with political officials, considering that they are not only pressured by competitors and customers (Sheth, 2011) but also by government entities (Iriyama et al., 2016). That is, political ties become not only a choice that may allow economic rents that may not internally possible but also a necessity for firm SME survival in such emerging economies (Sheng et al., 2011; Yeniaras et al., 2020).

Based on the pros and cons of both business and political ties, the extant literature calls for the inspection of the direct relationships of informal managerial ties to both incremental (i.e. exploitative) and renewing (i.e. exploratory) dynamic skills (Jansen et al., 2006).

To the best of our knowledge, thus far, a limited of number of studies have scrutinized direct relations (Jansen et al., 2006; Shu et al.2012; Yeniaras et al., 2020). Nonetheless, such attempts to analyze direct relations, especially in an emerging economy setting, neglect the fact that regenerative (i.e. organizational unlearning) dynamic capabilities should precede both incremental (i.e. exploitative) and renewing (i.e. exploratory) dynamic competencies (Zhao et al., 2013) to reconfigure existing internal and external resources. This is due to SMEs' limited access to equity capital in emerging economy contexts. The contemporary literature commonly suggests that unlike in political ties, the benefits obtained through business connections outweigh the costs of obtaining and cultivating such relationships. This effect is due to business ties being more reciprocal than political ones ( $\mathrm{Li}$ et al., 2008). In business relationships, such reciprocal links enable the firms to be more open to new methods, practices and routines obtained through the joint use of capabilities and resources with their business partners (Hagedoorn and Frankort, 2008). In addition, complementary or novel information that may advance the complexity and scope of organizational expertise ( $\mathrm{Li}$ and Sheng, 2011) might force a firm to leave behind old-fashioned practices and routines, as well as to discard outdated or 
misleading organizational knowledge, hence promoting unlearning at the organizational level. In political ties, however, while a firm (through the manager) may benefit from certain relational rents, the information received is lagged and at the industry level. More importantly, the bureaucratic nature of political actors (with whom the firm has connections through their managerial informal social ties) is hierarchical and rigid. This may diminish information sharing and inter-departmental collaboration. Such firms might find it difficult to abandon previously established routines to adopt new ones (Chung et al., 2016). Accordingly, we draw upon the notion of operational linkages (Cannon and Perreault, 1999), which implies that (business or political) parties in collaboration embrace norms and idiosyncratic routines because of such co-operation. Thus, we posit the following:

H1. (a) Business ties will be positively related to organizational unlearning, while (b) political ties will be negatively related to it.

\subsubsection{Organizational unlearning and exploratory/exploitative innovation}

Organizational learning is a twofold dynamic process that encapsulates exploration and exploitation (March, 1991). While, through the exploration process, an organization attempts to harness new methods, routines and procedures, what was previously learned could affect the adoption of new ways (Cegarra-Navarro and Sánchez-Polo, 2007). Megill (1997) applies the term organizational memory to refer to all active historical organizational information that is shared and preserved for future use. While organizational memory (through the preservation of routines and procedures) provides a certain sense of stability, it might also hinder the organization's propensity toward innovation and change in general. This is because organizations not only spend time and effort to conserve (obsolete) existing know-how and information but also to acquire new (market) expertise (Cegarra-Navarro and Sánchez-Polo, 2007). Such effort (which is costly not just in terms of time but also regarding storage and retrieval) leads to information overload (Grant, 1991). To bypass the negative aspects of organizational memory and overload, Bogenrieder (2002) believes that organizations need organizational unlearning (i.e. regenerative dynamic capability) to boost innovation (i.e. incremental and renewing dynamic competencies) at the corporate level. This is because market knowledge may quickly become outdated (Rampersad, 2004). Consequently, the organizational memory that could facilitate joint sensemaking and information sharing - if not renewed - might dilute the value of knowledge (Cegarra-Navarro et al., 2011). Hence unlearning - a firm's ability to ignore previously accumulated understanding and information, and which may hamper attaining organizational goals (De Holan et al., 2004) - creates a competitive advantage for the learning organization (Leal-Rodríguez et al., 2015). In the same vein, the extant literature reaffirms organizational unlearning as an antecedent of organizational learning (Hedberg, 1981; Tsang and Zahra, 2008; Zhao et al., 2013). Both the gradual alteration of existing resource configurations (i.e. exploitative innovation) and the acceptance of new business models through discontinuous renewal procedures (i.e. exploratory innovation) require an organization to unlearn accrued, antiquated, ineffective expertise, procedures, routines and data. Thus, we hypothesize the following:

H2. Organizational unlearning will be positively related to (a) exploratory and (b) exploitative innovation.

\subsubsection{Exploratory/exploitative innovation and non-financial firm performance}

The current literature mostly examines the relationship between exploratory and exploitative innovation and financial performance (Kollmann and Stöckmann, 2014; JiménezJiménez and Sanz-Valle, 2011; Lubatkin et al., 2006; Yeniaras and Unver, 2016). An exclusive focus on the financial facet of organizational performance may, however, prove to be insufficient to maintain competitiveness in modern markets (Kennerley and Neely, 2003). Strategic performance and customer capital are two non-financial firm performance measures. Strategic performance refers to an organization's competitive position in comparison to its major rivals (Zou and Cavusgil, 2002); its assessment encapsulates gaining a foothold in the market, increased product/firm awareness, responding to competitive pressure, and expanding to other markets (Chung, 2012). Customer capital is the revenue enhancing value that is enabled by the firm's relationship with its customers (Duffy, 2000). Specifically, strategic performance reflects the competitiveness with respect to a firm's major rivals (Zou and Cavusgil, 2002) and embodies a firm's foothold in the market, customers' awareness of the product/firm and the firm's ability to respond to competitive pressures (Chung and Kuo, 2018). Customer capital, which is a major basis for competitive advantage (Chang and Tseng, 2005), captures a firm's quality improvement efforts, customer recommendations and repeat purchases, as well as the firm's reputation in contrast to that of its competitors (Cegarra-Navarro and Sánchez-Polo, 2008).

The literature commonly associates the ability to simultaneously pursue exploration and exploitation with increased firm performance (Raisch and Birkinshaw, 2008; Kollmann and Stöckmann, 2014). Yet, previous studies tend to investigate the dissected relationships linking exploratory and exploitative innovation to new product performance (Yeniaras and Unver, 2016) and financial performance (Lubatkin et al., 2006; Kollmann and Stöckmann, 2014), but not the connections to non-financial firm performance. Exploratory innovation covers actions spanning "search, variation, risk taking, experimentation, play, flexibility, discovery [and] innovation" (March, 1991, p. 71). In addition, major novel designs, markets and channels are the consequences of exploratory innovation (Abernathy and Clark, 1985), which allow a firm to enhance its strategic position. Exploratory innovation efforts also enable firms to find fresh core competencies that are difficult for competitors to imitate. This, in turn, becomes an instrumental tool for firms to create unique value propositions and thereby establish higher customer satisfaction (Lubatkin et al., 2006; Kollmann and Stöckmann, 2014).

Exploitative innovation involves refining existing resources, which relate to incremental efforts that aim to expand already established competencies, strengthen contemporary designs and further efficiency and cost reductions relevant to the 
processes already present (Broekhuizen et al., 2017; Jansen et al., 2006); all this helps to better address changing market needs. Such cost advantages may be passed on to customers in the form of lower prices compared to competing products (Kim and Atuahene-Gima, 2010). The chief goal of such product refinement through incremental dynamic capabilities is to listen to customers' shifting needs and to determine the products they are seeking (Atuahene-Gima et al., 2005). In addition to building customer satisfaction via improved products, such skills not only enable firms to gain a foothold or respond to competitive pressures but also allow them to boost quality by decreasing the defects, costs and time associated with product development processes (O'Cass et al., 2014). Hence, engaging in exploitative innovation provides firms with greater provision of market and customer needs (Benner and Tushman, 2003; Atuahene-Gima and Murray, 2007; Belderbos et al., 2010) and helps them to achieve enhanced strategic performance. Therefore, we propose the following:

H3. Exploratory and exploitative innovation will be positively related to (a) customer capital and (b) strategic performance.

\subsubsection{Exploratory/exploitative innovation and financial performance}

Firms with renewing dynamic capabilities (i.e. exploratory innovation competencies) are able to offer novel, differentiated and unique products that allow them to both identify and open up new product-market opportunities to meet emerging customer needs. While the development of such dynamic skills is frequently costly and the return is often distant and uncertain (March, 1991), the generation of fresh routines, processes and technologies result in products that provide various advantages to customers (Jansen et al., 2006); hence enhanced firm performance (Bierly and Daly, 2007). While exploitative innovation capabilities serve best in relatively stable markets where perceived changes are at the minimum (Kim and Atuahene-Gima, 2010; Story et al., 2015), the growth of such capabilities is usually associated with high costs and failure risks (Gupta et al., 2006).

Nevertheless, incremental dynamic capabilities - which refer to the gradual adjustment of the existing resource alignment (Stopford and Baden-Fuller, 1994) - comprise an organization's capacity to act in response to current market needs. Accordingly, the organizational goal in cultivating incremental dynamic skills is to offer original products at lower costs in comparison to competitors (Smith and Tushman, 2005). Firms with exploitative innovation capabilities benefit from them in the form of enhancement in "automation and the productivity of existing product development technologies, machinery and routines" (O'Cass et al., 2014, p. 865). Such advances not only allow for more efficient use of organizational resources but also mitigate the costs and time involved (Morgan and Berthon, 2008) in product development processes, thereby boosting financial performance (Evanschitzky et al., 2012; Levinthal and March, 1993). Thus, we hypothesize the following:

H4. (a) Exploratory and (b) exploitative innovation will be positively related to financial performance.

\subsubsection{Business/political ties and exploratory/exploitative} innovation: the mediating role of organizational unlearning The conceptual framework and hypotheses we developed indicate the mediating effect of organizational unlearning. That is, we propose that organizational unlearning mediates the relationship between business and political ties and exploratory and exploitative innovation. A limited number of studies have examined the direct connections of business and political ties to exploratory and exploitative innovation (Kraft and Bausch, 2018; Shu et al., 2012; Yeniaras et al., 2020). However, as mentioned earlier, these investigations overlook the fact that in emerging economies, regenerative dynamic capabilities (i.e. organizational unlearning) should precede organizational learning (i.e. exploratory and exploitative innovation capacities) (Zhao et al., 2013). This is because firms in emerging economies commonly have limited access to equity capital and need to reconfigure their (limited) existing internal and external resources when building either exploratory or exploitative innovation skills. Both exploratory and exploitative dynamic competencies serve to increase organizational efficiency and reduce costs for stronger firm performance (Atuahene-Gima and Murray, 2007; Belderbos et al., 2010).

Nevertheless, fostering (Cegarra-Navarro and Sánchez-Polo, 2007), storing and retrieving dynamic capabilities (Bogenrieder, 2002) are costly. Due to their limited access to equity capital, firms - and SMEs in particular - that operate in a country with an emerging economy may acquire a certain competitive advantage in exploration and exploitation by updating and unlearning previously accrued knowledge and information, which may hinder organizational goals (De Holan and Phillips, 2004). Such a dynamic skill, which serves to deliberately and voluntarily discard obsolete data, standards and procedures (Tsang and Zahra, 2008; Cegarra-Navarro et al., 2013; de Holan and Phillips, 2011), could facilitate joint sensemaking and information sharing, consequently triggering both renewing and incremental dynamic skills. Furthermore, in line with Zahra et al. (2011), we suggest that organizational unlearning spans the intentional disruption of well-established organizational routines and processes (Zahra et al., 2011). In this study, we provide a literature-based impetus regarding how business and political ties enable (or hamper) organizational unlearning. Hence, in $H 1 a$ and $H 1 b$, we laid the theoretical framework for the dissected relationships of business and political ties to organizational unlearning. That is, we imply that business ties will positively correspond to organizational unlearning, while political ties will relate to it negatively. We argue that organizational unlearning should account for the connections of both business and political ties to exploratory and exploitative innovation. We thereby posit the following:

H5. Organizational unlearning will (a) positively mediate the relationship linking business ties to exploratory and exploitative innovation and (b) negatively mediate the relationship linking political ties to exploratory and exploitative innovation.

\subsubsection{Business/political ties and financial and non-financial performance: Serial mediation}

Earlier, we gave evidence in terms of the dissected relationships that connect business and political ties to organizational 
unlearning. Subsequent to providing the theoretical support regarding the pros and cons associated with business and political links, we indicated that business ties positively - and political ties negatively - relate to organizational unlearning. We identified the complementary, novel information that broadens the complexity and scope of organizational knowledge ( $\mathrm{Li}$ and Sheng, 2011) as relational rents that are received through business ties, which promote organizational unlearning at the corporate level.

In contrast, we provided the adoption of a rigid, more bureaucratic organizational structure and lagged industry-level information (obtained through political officials) as disadvantages associated with political ties, which may diminish a firm's ability to abandon norms and processes. In addition, the extant literature suggests that organizational unlearning should precede organizational learning (Tsang and Zahra, 2008; Zhao et al., 2013). Consistent with this literature, we implied that organizational unlearning should be positively linked to both exploratory and exploitative innovation.

The contemporary literature commonly associates a firm's ability to simultaneously pursue exploration and exploitation with organizational success (Auh and Menguc, 2005; Raisch and Birkinshaw, 2008). Despite this, few studies have examined the dissected relationships that connect exploratory and exploitative innovation to firm performance (Kollmann and Stöckmann, 2014; Yeniaras and Unver, 2016). In previous sections of this study, we pinpointed a literature-based impetus regarding such dissected relations. While former research has associated both business and political ties with financial outcomes (Luo and Chen, 1997) and firm performance in general (Li et al., 2008; Sheng et al., 2011), other studies have failed to establish empirical evidence of these significant links (Child and Tse, 2001; Lau et al., 2002). We believe that a potential explanation of mixed findings may be the failure in identifying possible intervening variables between business/ political ties and firm performance.

Hence, in this study, we demonstrate that organizational unlearning reinforces both renewing and incremental dynamic capabilities (i.e. exploratory and exploitative innovation), which, in turn, results in higher non-financial and financial firm performance. Such relationships point to a serial mediation whereby business and political connections indirectly relate to financial and non-financial performance through organizational unlearning and organizational learning, respectively. A serial mediation is a causal chain where mediators connect the independent to the dependent variables with a specified direction of causal flow (Hayes, 2012). In this respect, we assert that business ties are positively related to organizational unlearning (i.e. regenerative dynamic skills), which, in turn, are involved in exploratory and exploitative innovation that boost financial and non-financial firm performance. With a similar causal-chain logic, we indicate that political ties will limit organizational unlearning, which will impair a firm's renewing and incremental dynamic competencies, thus reducing the firm's financial and nonfinancial performance levels. In sum, we put forward the following:

H6. Organizational unlearning, exploratory innovation and exploitative innovation will (a) positively mediate the relationship connecting business ties to financial and non-financial performance and (b) negatively mediate the relationship linking political ties to financial and nonfinancial performance.

\section{Methods}

\subsection{Sample and data collection}

To test the conceptual model presented in Figure 1, we initially randomly selected and contacted 2,433 independent wholesalers and manufacturers that actively operate in three industries: electronics, food and construction. Out of 1,100 firms that agreed to participate in our study, we obtained a total of 302 usable questionnaires (response rate $=27.45 \%$ ). Of 1,100 managers that initially agreed to participate, 478 later became unresponsive and did not fill in the questionnaire. Of those remaining 622 participants, we obtained 302 completed the questionnaires fully, with no missing data points. That is, 320 out of 622 surveys had one or more missing data point. Subscribing to Harel et al. (2008), we use the de-facto method of handling missing values and use listwise deletion procedure. Considering that only a minority of scholars use multiple imputation, mean imputation, full information maximum likelihood or pairwise deletion (Harel et al., 2008), we opted to select the commonly used approach of listwise deletion. Nevertheless, listwise deletion may cause power and representativeness issues (Myers, 2011). Our data collection was done via face-to-face interviews. A vast majority of the participants that produced unusable surveys, although we met them face-to-face, decided not to provide answers to the items in questionnaire after we asked read them the initial few items. These managers were almost evenly distributed across all three industries with 92 in construction, 120 in food and 108 in electronics industries.

The size of the firms varied from a low of 10 to 150 full-time employees. Of the 302 enterprises, $37 \%$ are in construction (110 firms), 32\% are in electronics (94 firms) and 32\% are in the food industry ( 98 firms). Firm age varied from as low as one year in active operation to 71 years. The average firm age was 13 years. The detailed descriptive statistics, inter-correlations and reliability statistics for the multi-item measurements that we used are presented in Table 1 .

To ascertain whether the respondents who participated fit the intended target group, we first contacted the firms that opted to join. Subsequently, we only administered the survey instruments to senior managers at the firms. To translate the English of the survey instrument to Turkish, we had a native Turkish speaker who is also fluent in English translate the items from English to Turkish. Next, a different person who is proficient in both languages translated the survey back into English. Subsequently, both the research team and the translators adjusted the items in line with the current literature (Dayan et al., 2016). We also did a series of pretests prior to data collection. First, we contacted nine randomly chosen managers and had them evaluate the content and meaningfulness of the items. Next, we contacted four academics that work in relevant areas for their comments on the suitability of the scale items. Finally, we revised the items based on the feedback we received from both the managers and the academics. 


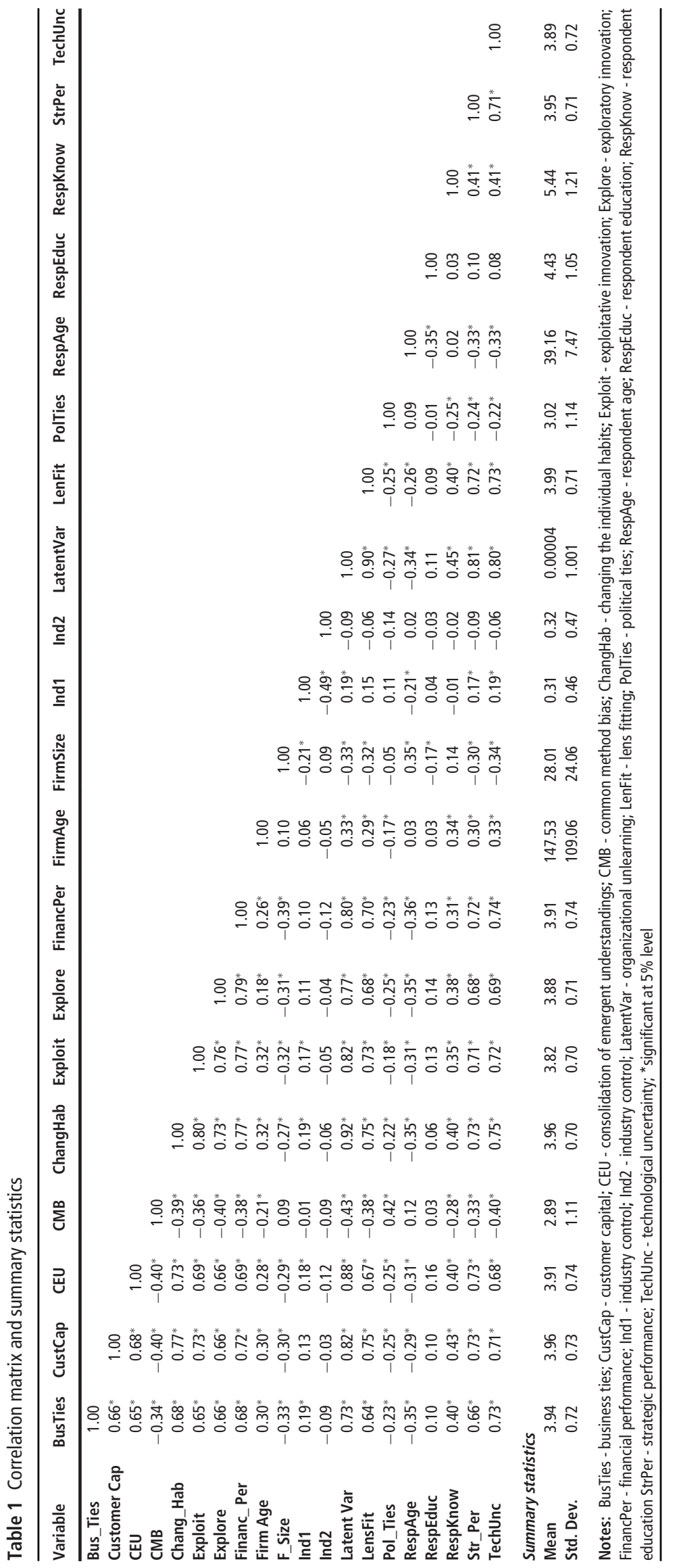




\subsection{Measures}

In this study, we used first-order reflective and formative measures in examining the relationships displayed in Figure 1. In addition, we gauged organizational unlearning as a first-order reflective and a second-order formative construct. Following preceding literature on the direction of the causality between the latent and observed indicators (Jarvis et al., 2003), we treated political ties as a reflective scale (Li and Zhang, 2007; Peng and Luo, 2000) and business ties as a formative scale (Sheng et al., 2011). For business ties that captured managerial informal social connections with market players (e.g. buyers, suppliers, collaborators, competitors), we adopted a five-item, five-point Likert scale ( 1 = strongly disagree, $5=$ strongly agree $)$ from Dubini and Aldrich (1991) and Peng and Luo (2000). Political links represented the extent of managerial informal connections, with political representatives at different positions (e.g. government legislatures, tax bureaus and state banks). We assessed political relationships through a five-item, five-point Likert scale ( $1=$ strongly disagree, 5 = strongly agree) adapted from Peng and Luo (2000) and Sheng et al. (2011). We measured business ties as a formative scale and political ties as a reflective scale because political ties relate to relationships with political actors, while business ties embody relationships with different actors such as suppliers, customers and collaborators (Sheng et al., 2011).

Following Cegarra-Navarro et al. (2016) and CegarraNavarro and Sánchez-Polo (2008), we conceptualized organizational unlearning as a first-order reflective and a second-order formative construct. Organizational unlearning is mostly conceptualized as a facilitator, which allows organizations to acquire new knowledge, which usually conflicts with the existing knowledge. Departing from the extant literature (Sinkula, 2002) organizational unlearning is mostly operationalized as the openness to changes in routines. For that, drawing from previous studies such as Lewin (1951) and Cegarra-Navarro and Sancez-Vidal (2008), we operationalized organizational unlearning as a three-dimensional construct. The first-order scales were the consolidation of emergent understandings, the examination of lens fitting and the framework for changing individual habits. We computed all first-order dimensions with a four-item, five-point Likert scale ( 1 = strongly disagree, $5=$ strongly agree $)$. The consolidation of emergent understandings refers to the organizational ability to make changes that need to be made to consistently produce new ideas and methods. The examination of lens fitting is an organization's capacity to identify outdated perspectives. Finally, the framework for changing individual habits involves a firm's ability to avoid relying on current beliefs and techniques (Cegarra-Navarro et al., 2016). We determined a firm's exploratory and exploitative innovation capabilities through a five-point Likert scale ( 1 = strongly disagree, 5 = strongly agree). Based on prior research on innovation competencies, we opted for the conventionally used indicators of exploratory and exploitative innovation scales by Jansen et al. (2006).

To determine the non-financial performance implications of the proposed antecedents, we used two first-order reflective scales: customer capital and strategic performance. We operationalized customer capital through a five-point Likert scale adapted from Cegarra-Navarro and Sánchez-Polo (2008). The anchors of this customer capital scale that encompass a firm's effort to improve quality, customer recommendations, customers' repeat purchases and firm reputation and prestige, ranged from 1 (strongly downward) to 5 (strongly upward). Strategic performance - which refers to a firm's competitive position with respect to its major rivals - assesses senior managers' perceptions of their firms' performance levels in terms of gaining a foothold in the market, increased awareness of their products/firms, and their responsiveness to competitive pressures; we evaluated this aspect with a five-point Likert scale. We used the strategic performance scale from the relevant literature (Chung, 2012; Chung and Kuo, 2018). We scrutinized the financial facet of performance via a seven-item, five-point Likert scale adapted from Joshi and Sharma (2004). The respondents were asked to judge the financial performance of their organization for the past three years with regard to their main competitors on returns on investment, returns on sales, returns on assets, sales growth and market share growth.

We controlled for both the performance measures and innovation capabilities for several control variables including firm age, firm size, industry effects, level of respondents' knowledge of concepts under investigation, the respondents' education levels, respondents' age, dynamic demand and technological uncertainty. We based the selection of the control variables on the extant literature. Previous research has recognized a number of organizational variables as correlates of organizational skills and firm performance (i.e. firm size, firm age and industry effect) (Yeniaras and Unver, 2016). We controlled for both innovation competencies and firm performance measures for firm size to minimize the effect of economies and diseconomies of scale (Bain, 1968). We calculated firm age by taking its natural logarithm. We also gauged firm size level by taking the natural logarithm of the firms' total number of employees. To partial out the potential influences of industry affiliation, we asked the respondents to state the main industry in which they operated, and grouped them under three key industries (construction, electronics and food). To minimize response bias (James et al., 1984), we controlled for both performance measures and innovation capabilities for the respondents' age, knowledge and education. To partial out the possible effects of external environmental factors and to observe the direct relationships, we controlled for both innovation capabilities and performance measures for technological uncertainty. We assessed technological uncertainty using Jaworski and Kohli's (1993) four-item, fivepoint Likert scale $(1=$ strongly disagree, $5=$ strongly agree $)$.

Finally, to minimize the common method bias effect on the dependent variables, we controlled for innovation skills and firm performance measures for negative affectivity bias (Watson et al., 1988). Negative affectivity bias is not theoretically linked to any of the variables used in our study (Yeniaras and Unver, 2016). The items for the scale of negative affectivity ( 1 = strongly disagree, $5=$ strongly agree) are as follows:

- "Minor setbacks tend to irritate me too much";

- "Often, I get irritated at little annoyances"; and

- "There are days when I am 'on-edge' all of the time" (Yannopoulos et al., 2012).

\subsection{Model estimation}

The first-order and second-order formative measurements that we used in this study, among other reasons that will be 
discussed, required us to use partial least squares structural equation modeling (PLS-SEM) with SmartPLS v.3.2.7 software (Ringle et al., 2015). In addition, PLS-SEM allowed us to investigate a relatively complex model that incorporates both direct and indirect relationships with a relatively smaller sample size (Hair et al., 1998). This property of PLS-SEM fits the exploratory nature of our study. Additionally, PLS minimizes erroneous interpretations in the examination of the proposed relationships (Sarstedt et al., 2014) and is comparable to conventional covariance-based SEM, such as AMOS. We evaluated the proposed model in two steps: the outer (measurement) model and the inner (structural) model (Hair et al., 2013). We then applied the resampling procedures (i.e. bootstrapping) to 500 resamples (Hair et al., 2012). In addition, as an exploratory attempt, in this study, we examine the direct relations among business, political ties and exploratory and exploitative innovation. That is because business and political ties have been found to be positively related to market ( $\mathrm{Li}$ and Zhang, 2007) and financial performance, as well as innovativeness of the firm (Chetty and Stangl, 2010; Sheng et al., 2011; Yeniaras et al., 2020). Nevertheless, less is documented on the usefulness of business and political ties in pursuing exploitative and exploratory innovations. Accordingly, to add to the extant literature, in addition to our hypothesized model, we scrutinize and report the direct effects of business and political ties to innovation capabilities and performance measures.

\section{Results}

\subsection{Outer model results}

Formative indicators require a different approach to the conventional factor and internal consistency analyses (Diamantopoulos and Winklhofer, 2001). Consequently, we opted for Diamantopoulos and Winklhofer's (2001) four-step approach in scrutinizing the relationship linking business and political ties to organizational unlearning and innovation capabilities to firm performance. The same technique, as proposed by Diamantopoulos and Winklhofer (2001), was also used by Sheng et al. (2011) in their investigation of the relationships of both business and political ties to firm performance. These four steps are:

1 content specification,

2 indicator specification,

3 the indicator collinearity test and

4 the external validity test.

First, to determine content specification, we contacted nine randomly chosen senior managers and conducted in-depth interviews with them to specify the domain and scope of the content of formative scales used in our study (i.e. business ties and organizational unlearning). Next, as in formative scales, each indicator needs to uniquely relate to the latent variable, we evaluated the suitability of business ties and organizational unlearning by assessing the multicollinearity among their indicators. A high multicollinearity level typically signals a problematic validity assessment of the indicator (Diamantopoulos and Winklhofer, 2001). The maximum variance inflation factor (VIF) for business ties and organizational unlearning were 2.512 and 2.863, respectively, well below the suggested threshold of 5 . Consequently, multicollinearity was not a primary concern for formative scales. In addition, all of the VIF values of items used in this study were smaller than 3.930, providing empirical evidence of a minimal concern for common method bias (Kock and Lynn, 2012).

To assess convergent validity, we analyzed the nomological network of the formative business ties scale. Prior studies have established a positive relationship between business ties (Peng and Luo, 2000; Sheng et al., 2011) and organizational unlearning (Cegarra-Navarro et al., 2016; Cegarra-Navarro and Sánchez-Polo, 2008) to firm performance. We confirmed that business ties $(r=0.705)$ and organizational unlearning $(r=$ 0.802 ) are correlated with financial performance. In addition, each indicator of business significantly correlated with financial performance $(r=0.370-0.645)$, thus demonstrating external validity. Similarly, each indicator of organizational unlearning significantly correlated with firm performance $(r=0.271-$ 0.557).

We also assessed the convergent validity, internal consistency and discriminant validity of the reflective measurements. Subscribing to Nunnally (1978), we used item reliability to evaluate the internal consistency of the measurements. The items of all reflective variables had statistically significant loadings over 0.60 , as advised by Nunnally (1978), illustrating evidence of internal consistency. It should be noted that the in a formative measurement, the measured variables are uncorrelated by nature. In addition, formative constructs that are previously validated are considered significant (Thornton et al., 2014; Zacca et al., 2015). Accordingly, factor loadings of business ties are not reported. Next, we calculated the composite reliability (CR) scores. We found that all CR values were above the 0.70 benchmark. In addition, the average variance extracted (AVE) scores were over 0.50. The square of the inter-correlations between two constructs, $\phi^{2}$, was less than the AVE estimates of the two constructs for all pairs of constructs (Fornell and Larcker, 1981), establishing additional evidence of discriminant validity. All of the reflective measurement constructs used in this study fulfilled these requirements. Table 2 provides details on the factor loadings, CRs, AVEs and reliability statistics.

Next, we calculated the VIF values for latent constructs to test multicollinearity (Wilden et al., 2013). The VIF values of the reflective measures ranged from a low of 1.320 to a high of 3.930, below the cutoff value of 5 (Hair et al., 1998). Finally, we calculated the Heterotrait-Monotrait (HTMT) ratios (Henseler et al., 2015). The HTMT ratios were all below 0.85, while the upper confidence bounds (97.5\%) are less than 1, which shows discriminant validity in the data. Such results imply that the reflective measurement model fits the data well.

\subsection{Inner model results}

As depicted in Model 1 in Figure 2 below, we examined both direct and indirect relationships as part of this study. We first looked at the hypothesized direct effects of:

- business and political ties on organizational unlearning;

- organizational unlearning on innovation capabilities; and

- innovation capabilities on firm performance (i.e., customer capital, strategic performance, financial performance). 
Table 2 Reliability and validity tests for the complete data

Constructs

Business ties formative scale (formative scale)

Top managers at our firm have built good connections with managers at the supplier firms

Top managers at our firm have built good connections with managers at the customer firms

Top managers at our firm have built good connections with managers at the competitive firms

Top managers at our firm have built good connections with managers at the marketing based collaborators

Top managers at our firm have built good connections with managers at the technological collaborators

Political ties $(\alpha=0.92 ; C R=0.94 ; A V E=0.81)$

Top managers at our firm have maintained good personal relationships with officials in various levels of government

Top managers at our firm have developed good connections with officials in regulatory and supporting organizations

such as tax bureaus, state banks and commercial administration bureaus

So far, our firm's relationship with regional government officials has been in a good shape

Our firm has spent substantial resources in building relationships with government officials

The consolidation of emergent understandings ( $\alpha=0.80 ; C R=0.87 ; A V E=0.63$ )

This organization seems to be open to new ideas and new ways of doing things

Management tries to initiate projects and introduce innovations

This organization recognizes the value of new information, assimilate it and apply it

Managers are prone to collaborate with members of the organization and to solve problems together

The examination of lens fitting (Cegarra-Navarro and Sánchez-Polo, 2008) $(\alpha=0.85 ; C R=0.90 ; A V E=0.69$ )

0.809

This organization is able to identify problems (new ways of doing things) easily

In this organization, we are able to see mistakes from our colleagues

0.882

This organization is able to listen to its customers (e.g. complaints, suggestions)

0.860

In this organization, we are able to share information with our boss easily

The framework for changing the individual habits $(\alpha=0.82 ; C R=0.88 ; A V E=0.65$ )

New situations help us visualize our mistakes

New situations have changed our way of thinking

New situations have changed my behaviors

New situations have supported me questioning our behaviors

Exploratory innovation (Jansen et al., 2006) $(\alpha=0.87 ; C R=0.90 ; A V E=0.56$ )

Our organization accepts demands that go beyond existing products and services

We invent new products and services

We experiment with new products and services in our local market

We commercialize products and services that are completely new to our organization

We frequently use new opportunities in new markets

Our organization regularly uses new distribution channels

We regularly search for and approach new clients in new markets

Exploitative innovation ( $\alpha=0.89 ; C R=0.91 ; A V E=0.60$ )

We frequently refine the provision of existing products and services

We regularly implement small adaptations to existing products and services

We introduce improved, but existing products and services for our local market

We improve our provision's efficiency of products and services

We increase economies of scales in existing markets

Our organization expands services for existing clients

Technological turbulence $(\alpha=0.81 ; C R=0.88 ; A V E=0.64)$

The technology in our industry is changing rapidly

It is very difficult to forecast the technology development direction in our industry

Customer capital $(\alpha=0.86 ; C R=0.90 ; A V E=0.70)$

Improvement of quality 
Table 2

\begin{tabular}{lr}
\hline Constructs & Factor loadings \\
\hline Good reputation and prestige & 0.812 \\
Strategic performance $(\alpha=0.84 ; C R=0.89 ; A V E=0.68)$ & 0.744 \\
We gained a foothold in the market & 0.865 \\
Increased product/firm awareness & 0.865 \\
Responded to competitive pressure & 0.810 \\
Expanded to other markets & 0.650 \\
Financial performance $(\alpha=0.90 ; C R=0.92 ; A V E=0.63)$ & 0.841 \\
Profitability & 0.868 \\
Return on investment & 0.821 \\
Return on sales & 0.850 \\
Growth in profits & 0.758 \\
Return on equity & 0.729 \\
Growth in sales & \\
Growth in market share & \\
\hline
\end{tabular}

Figure 2 Direct and indirect relations

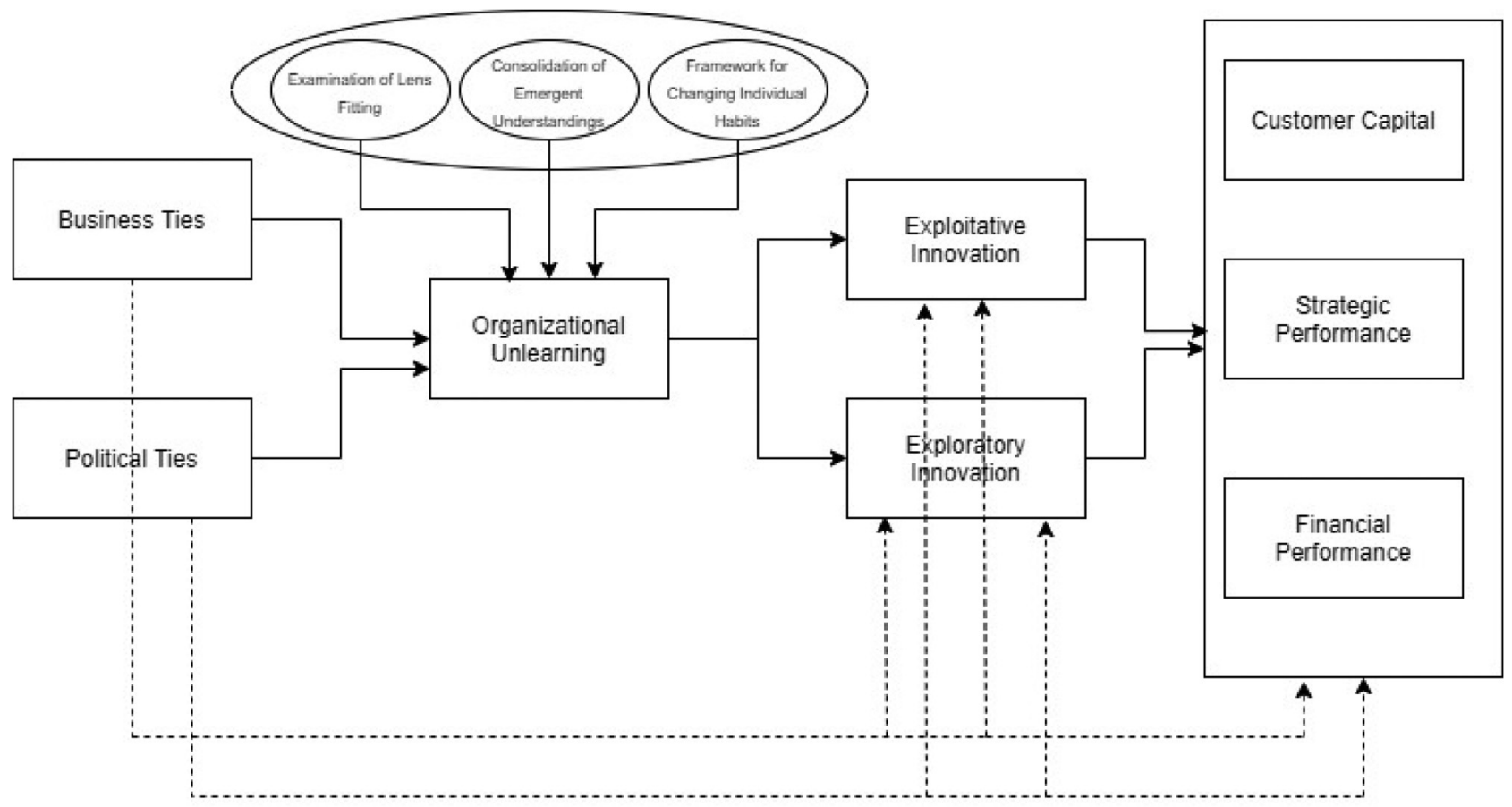

Notes: Dotted lines represent indirect relations

The findings indicate that business ties are positively related to organizational unlearning ( $\beta=0.704, t=10.798$ ), providing support for H1a. Conversely, political ties are negatively associated with organizational unlearning $(\beta=-0.102, t=$ 1.689), which demonstrates support for $H 1 b$. In $H 2 a$, we suggested a positive relationship between organizational unlearning and exploratory innovation. The outcomes suggested that organizational unlearning is positively connected to exploratory innovation $(\beta=0.679, t=11.720)$, which provides support for $2 \mathrm{a}$. In $H 2 b$, we hypothesized a positive association between organizational unlearning and exploitative innovation. The results offer empirical support for the positive relationship between organizational unlearning and exploitative innovation ( $\beta=0.564, t=7.835)$. As part of $H 3$, we scrutinized the connection linking exploratory and exploitative innovation to customer capital $(\mathrm{H} 3 \mathrm{a})$ and strategic performance $(H 3 b)$. The results establish an empirical basis for both hypotheses. We found that exploratory innovation is positively connected to customer capital $(\beta=0.090, t=1.311)$ and to strategic performance $(\beta=0.188, t=2.420)$. In addition, exploitative innovation is positively linked to customer capital $(\beta=0.356, t=4.640)$ and strategic 
performance ( $\beta=0.281, t=3.625$ ). However, it may be said that we could only provide a weak support to $H 3$ a (i.e. relation of exploratory innovation to customer capital) as the effect is marginally significant at $10 \%$.

$\mathrm{H} 4 \mathrm{a}$ and $\mathrm{H} 4 \mathrm{~b}$ propose positive relationships between both exploratory and exploitative innovation and financial performance. Both exploratory $(\beta=0.363, t=5.563)$ and exploitative innovation $(\beta=0.257, t=2.882)$ relate positively to financial performance, demonstrating support for $H 4 a$ and $H 4 b$, respectively. We provide the direct-effect results in Table 3.

In $H 5$, we look at the indirect relationships linking business $(\mathrm{H} 5 \mathrm{a})$ and political ties $(\mathrm{H} 5 \mathrm{~b})$ to exploratory and exploitative innovation through organizational unlearning. The findings offer empirical evidence for both hypotheses. We discovered that organizational unlearning positively mediates the relationship between business ties and exploratory innovation ( $\beta=0.397, t=5.955)$. We found that organizational unlearning positively mediates the relationship between business ties and exploitative innovation $(\beta=0.478, t=$ 7.928). In contrast, organizational unlearning negatively mediates the relationship between political ties and exploratory innovation ( $\beta=-0.058, t=1.667)$. Moreover, organizational unlearning negatively mediates the relationship between political ties and exploitative innovation $(\beta=-0.070, t=$ 1.653). These findings establish empirical evidence for $\mathrm{H} 5 \mathrm{a}$ and $H 5 b$.

\subsection{Post hoc analysis}

In H6a, we assert that organizational unlearning and exploratory innovation positively mediate the relationship connecting business ties to customer capital, and to strategic and financial performance, respectively. By contrast, in $H 6 b$, we imply that political ties will relate negatively to customer capital, strategic and financial performance, respectively, through organizational unlearning and exploratory innovation. We provide a summary of all indirect relationships in Table 4. Our findings provide partial empirical evidence for H6a and $H 6 b$. Surprisingly, in similar mediation models where organizational unlearning and exploratory innovation were serial mediators, neither business ties $(\beta=0.036, p=0.114$ ) nor political ties $(\beta=-0.005, p=0.187)$ indirectly relate to customer capital. Nevertheless, both business and political ties are associated with financial and non-financial firm performance, as proposed. That is, business ties indirectly and positively relate to performance measures where we identified negative, indirect relationships between political ties and performance measures. Nevertheless, the indirect relations of political ties to strategic and financial performance through organization unlearning and exploration are only marginally significant at $10 \%$ level and we could only provide weak support for them. Similarly, only a weak support (i.e. significance at $10 \%$ level) was provided for the indirect relations of political ties to customer capital, strategic and financial performance through organizational unlearning and exploitation. Such findings should be approached with caution.

To avoid any possible biased conclusions about the mediating effects, we added several direct relations into the model. First, we examined the direct relations of business and political ties to exploratory and exploitative innovation. Second, we also look into the direct effects of business and political ties to performance measures. The results provided supportive evidence to the necessity of including organizational unlearning as a mediating mechanism between social managerial ties and innovation capabilities. That is, we found no significant direct relations (at conventional levels) of business ties to exploitative innovation $(\beta=0.079, t=0.964$, $p=0.168)$, financial performance $(\beta=0.070, t=1.398, p=$ $0.081)$, customer capital $(\beta=0.133, t=1.698, p=0.168)$ and strategic performance ( $\beta=0.122, t=1.254, p=0.105)$, except for the direct relation of business ties to exploratory innovation ( $\beta=0.164, t=2.270, p=0.012$ ). As for the direct relations of political ties to exploratory innovation $(\beta=-0.010, t=0.191$, $p=0.424)$, exploitative innovation $(\beta=-0.052, t=0.854, p=$ $0.197)$, financial performance $(\beta=-0.030, t=0.682, p=$ 0.248 ), customer capital ( $\beta=-0.037, t=0.749, p=0.227$ ) and strategic performance $(\beta=-0.059, t=1.167, p=0.122)$ we found no significant relationships. Mostly insignificant direct relations of business and political ties to innovation capabilities and performance measures provided further evidence regarding the necessity of including the mediating mechanisms. The significant direct relation of business ties to exploratory innovation provided empirical evidence to suggest a complementary mediation of organizational unlearning on the aforementioned relation. A complimentary mediation is when both the mediated effect and the direct effect are significant and have the same relational direction. The mediated relation of business ties to exploratory innovation

Table 3 Results of analyzes on hypothesized direct relationships

\begin{tabular}{|c|c|c|c|c|c|c|}
\hline \multicolumn{2}{|c|}{ Hypothesized association } & \multirow{2}{*}{$\frac{\text { Expected sign }}{+}$} & \multirow{2}{*}{$\frac{\text { Standardized coefficient }}{0.704}$} & \multirow{2}{*}{$\frac{\text { SD }}{0.063}$} & \multirow{2}{*}{$\frac{p \text {-value }}{0.000}$} & \multirow{2}{*}{$\begin{array}{l}\text { Status } \\
\text { Supported }\end{array}$} \\
\hline H1a & Business ties $\rightarrow$ Org Unl. & & & & & \\
\hline$H 1 b$ & Political ties $\rightarrow$ Org Unl. & - & -0.102 & 0.058 & 0.04 & Supported \\
\hline$H 2 a$ & Org Unl. $\rightarrow$ Explore & + & 0.564 & 0.074 & 0.003 & Supported \\
\hline$H 2 b$ & Org Unl. $\rightarrow$ Exploit & + & 0.679 & 0.044 & 0.059 & Supported \\
\hline H3a & Explore $\rightarrow$ Customer capital & + & 0.090 & 0.062 & 0.100 & Partially supported \\
\hline$H 3 b$ & Explore $\rightarrow$ Strategic performance & + & 0.188 & 0.081 & 0.010 & Supported \\
\hline$H 4 a$ & Explore $\rightarrow$ Financial performance & + & 0.363 & 0.072 & 0.000 & Supported \\
\hline H3a & Exploit $\rightarrow$ Customer capital & + & 0.356 & 0.074 & 0.000 & Supported \\
\hline$H 3 b$ & Exploit $\rightarrow$ Strategic performance & + & 0.281 & 0.077 & 0.000 & Supported \\
\hline$H 4 b$ & Exploit $\rightarrow$ Financial performance & + & 0.257 & 0.092 & 0.003 & Supported \\
\hline
\end{tabular}

Notes: Org Unl - organizational unlearning; Explore - exploratory innovation; Exploit - exploitative innovation 
Table 4 Results of analyzes on hypothesized indirect relationships

\begin{tabular}{|c|c|c|c|c|c|}
\hline & & Path coefficients & Standard deviation & $p$-values & Status \\
\hline H5a & BT $\rightarrow$ Org.Unl. $\rightarrow$ Explore & 0.397 & 0.066 & 0.000 & Supported \\
\hline$H 5 b$ & PT $\rightarrow$ Org.Unl. $\rightarrow$ Explore & -0.058 & 0.034 & 0.044 & Supported \\
\hline H5a & BT $\rightarrow$ Org.Unl. $\rightarrow$ Exploit & 0.478 & 0.058 & 0.000 & Supported \\
\hline$H 5 b$ & PT $\rightarrow$ Org.Unl. $\rightarrow$ Exploit & -0.070 & 0.041 & 0.043 & Supported \\
\hline H6a & BT $\rightarrow$ Org.Unl. $\rightarrow$ Explore $\rightarrow$ Customer capital & 0.036 & 0.030 & 0.114 & Not supported \\
\hline H6a & BT $\rightarrow$ Org.Unl. $\rightarrow$ Explore $\rightarrow$ Strategic performance & 0.074 & 0.035 & 0.017 & Supported \\
\hline H6a & BT $\rightarrow$ Org.Unl. $\rightarrow$ Explore $\rightarrow$ Financial performance & 0.114 & 0.039 & 0.000 & Supported \\
\hline$H 6 b$ & PT $\rightarrow$ Org.Unl $\rightarrow$ Explore $\rightarrow$ Customer capital & -0.005 & 0.006 & 0.187 & Not supported \\
\hline$H 6 b$ & PT $\rightarrow$ Org.Unl. $\rightarrow$ Explore $\rightarrow$ Strategic performance & -0.011 & 0.008 & 0.090 & Partially supported \\
\hline$H 6 b$ & PT $\rightarrow$ Org.Unl. $\rightarrow$ Explore - $>$ Financial performance & -0.021 & 0.014 & 0.063 & Partially supported \\
\hline H6a & BT $\rightarrow$ Org.Unl. $\rightarrow$ Exploit $\rightarrow$ Customer capital & 0.170 & 0.041 & 0.000 & Supported \\
\hline H6a & BT $\rightarrow$ Org.Unl. $\rightarrow$ Exploit $\rightarrow$ Strategic performance & 0.135 & 0.042 & 0.001 & Supported \\
\hline H6a & BT $\rightarrow$ Org.Unl. $\rightarrow$ Exploit $\rightarrow$ Financial performance & 0.123 & 0.047 & 0.005 & Supported \\
\hline$H 6 b$ & PT $\rightarrow$ Org.Unl. $\rightarrow$ Exploit $\rightarrow$ Customer capital & -0.025 & 0.016 & 0.060 & Partially supported \\
\hline$H 6 b$ & PT $\rightarrow$ Org.Unl. $\rightarrow$ Exploit $\rightarrow$ Strategic performance & -0.020 & 0.013 & 0.072 & Partially supported \\
\hline$H 6 b$ & PT $\rightarrow$ Org.Unl. $\rightarrow$ Exploit $\rightarrow$ Financial performance & -0.018 & 0.012 & 0.072 & Partially supported \\
\hline
\end{tabular}

Notes: BT - business ties; PT - political ties. Org. Unl. - organizational unlearning; Explore - exploratory innovation. Exploit - exploitative innovation

through organizational unlearning was $(\beta=0.359, t=5.614$, $p=0.000)$ and its direct relation to exploratory innovation was ( $\beta=0.164, t=2.270, p=0.012$ ) with the same directional relation. The insignificant, direct relations of business and political ties to both innovation capabilities and performance measures indicated an indirect-only mediation (Zhao et al., 2013). An indirect-only mediation is when there is a mediated effect but no direct relationship. These findings further strengthen our hypothesized indirect-effect only model. The summary of the direct and significant indirect relations with the added direct paths may be found below in Table 5 .

\section{Discussion}

Our outcomes contribute to a relatively new stream of research on relational governance (Chung et al., 2016; Dong et al., 2013; Sheng et al., 2011; Zhang et al., 2015) and dynamic capabilities theory (Ambrosini and Bowman, 2009). In particular, we have noted the attention paid to how firms (re)configure and integrate their integral competencies, making use of their relational ties in the emerging country context (Chen et al., 2018; Forkmann et al., 2018; Liu et al., 2018). Drawing on these theories, we explored the role of regenerative, renewing and incremental dynamic skills on the relationship between managerial informal social ties (i.e. business and political connections) to non-financial and financial firm performance. Although emerging economies provide greater growth opportunities for firms, the marketing literature seems to not be giving them the attention they deserve (Johnson and Tellis, 2008). The extant literature on business and political ties in the emerging economy context are mostly based in East Asia (Chung, 2011; Sheng et al., 2011). Additionally, instead of investigating the underlying mechanisms between managerial informal social ties and firm performance, these studies mainly focus on the direct relationship to (mostly financial) firm performance ( Sheng et al.,

Table 5 Results of analyses with added direct relations

\begin{tabular}{lrr}
\hline Direct association & Standardized coefficient & SD \\
\hline BT $\rightarrow$ Explore & 0.164 & 0.073 \\
BT $\rightarrow$ Exploit & 0.079 & 0.012 \\
PT $\rightarrow$ Explore & -0.010 & 0.077 \\
PT $\rightarrow$ Exploit & 0.052 & 0.054 \\
BT $\rightarrow$ Customer capital & 0.133 & 0.059 \\
BT $\rightarrow$ Strategic performance & 0.122 & 0.079 \\
BT $\rightarrow$ Financial performance & 0.070 & 0.197 \\
PT $\rightarrow$ Customer capital & -0.037 & 0.168 \\
PT $\rightarrow$ Strategic performance & -0.059 & 0.052 \\
PT $\rightarrow$ Financial performance & -0.030 & 0.047 \\
Org Unl. $\rightarrow$ Explore & 0.510 & 0.081 \\
Org Unl. $\rightarrow$ Exploit & 0.661 & 0.227 \\
Significant indirect associations with added direct effects & & 0.122 \\
BT $\rightarrow$ Org.Unl. $\rightarrow$ Explore & & 0.042 \\
\end{tabular}

Notes: BT - business ties; PT - political ties. Org. Unl. - organizational unlearning; Explore - exploratory innovation. Exploit - exploitative innovation 
2011; Wu, 2011; Zhang et al., 2015; Zhou and Poppo, 2010). To clarify the domain, we used a non-East Asian, important emerging country (Turkey) and analyzed the mediating effects of dynamic capabilities (i.e. regenerative, renewing and incremental) between managerial informal social ties and non-financial and financial firm performance.

Our first finding relates to the identification of the relationships linking business and political ties to regenerative dynamic capabilities, namely, organizational unlearning. We found that business ties are positively associated with organizational unlearning, but (as hypothesized) that political ties are negatively related to it. While this study might only be considered a snapshot of the connection between relational governance mechanisms and dynamic competencies, the aforementioned outcome is critical as it offers a wider perspective regarding the dissected relationships between different types of managerial informal social ties and regenerative, renewing and incremental dynamic skills, in addition to firm performance. Second, and just as important, we identified the positive relationships linking business ties to both renewing (i.e. exploratory innovation) and incremental (i.e. exploitative innovation) capabilities; conversely, we found negative, indirect relations with political ties. Such positive and negative indirect connections are explained (mediated) by organizational unlearning.

Our results provide empirical evidence to suggest that while both kinds of managerial informal relationships carry their own benefits, political ties hamper firms from building regenerative dynamic skills (i.e. organizational unlearning). In turn, this hampers firms' ability to develop their renewing (i.e. exploratory innovation) and incremental (i.e. exploitative innovation) dynamic competencies. Such findings establish an empirical basis for studies that have implied that business and political ties are double-edged swords (Dong et al., 2013) via data-driven studies to demonstrate that political ties do, in fact, carry disadvantages as they weaken firms' ability to unlearn, and consequently explore and exploit. This study also addresses the important question "Where does a firm's strategy come from?" (Gavetti and Rivkin, 2007, p. 420). Third, we attempted to explain the underlying mechanisms that link business and political ties to non-financial and financial firm performance. We found that the performance implications of business ties, as mediated by organizational unlearning and organizational learning, are mostly positive. However, political ties are primarily (indirectly) negatively connected to both nonfinancial and financial performance measures.

This study makes three important theoretical and empirical contributions to the literature. First, we added to the literature by dissecting not only managerial social ties but also strategic renewal, to exploratory innovation and exploitative innovation, reflecting the perspective of renewing and incremental dynamic capabilities (Barreto, 2010; Teece, 2007). In addition, drawing upon dynamic capabilities theory, we suggest that the economic rents obtained through business and political ties might only be used to develop renewing and incremental dynamic competencies through regenerative dynamic capacities (Ambrosini and Bowman, 2009). That is, we indicate that firms with organizational unlearning capabilities are better able to cultivate their exploratory and exploitative innovation skills, as they can reconfigure resources obtained through managerial informal social ties as sources of competitive advantage (Abraham et al., 2012; Teece, 2007) in the form innovation capabilities. While there have been previous attempts to integrate relational governance with dynamic capabilities theory by examining the relationships linking managerial ties to dynamic capabilities (such as marketing, research and development and production capabilities) (Heirati and O'Cass, 2016), the literature has largely overlooked regenerative skills as a mediating mechanism. Our empirical investigation provided dissected results regarding the effects of business and political ties, thereby supporting the extant body of research; this suggests that managerial informal social ties carry both sweet and bitter sides (Gao et al., 2017).

Second, our theoretical justification, as well as our empirical findings, underscore the importance of understanding dissected managerial informal social ties as they relate to business and political connections (Sheng et al., 2011); the reason is to clarify their respective links to firm performance through mediating mechanisms of choice. This finding is in line with Brozovic's (2018) study, which implies that knowledge heterogeneity caused by relational rents enables firm access to otherwise inaccessible or scarce resources. Though grounded in a similar premise, our empirical results illustrate that this relationship might not always be direct. Due to the reciprocal nature of business ties relative to political ones (Li et al., 2009), we revealed a positive relationship between business ties and organizational unlearning, strategic renewal (i.e. exploratory and exploitative innovation), and firm performance in general, and a negative relationship between political ties and these outcomes.

Given the mixed results of social ties on firm performance and above arguments and reasoning, we did not notionally hypothesize for the direct effects of business and political ties to firm performance as the theoretical path does not clearly and directly links especially political ties to firm performance. Do the social ties matter for the firm performance? The evidence presented in our manuscript supports the prediction that business ties would matter more for the firm performance (same hypothesized by Sheng et. al., 2011), but does not clearly identify how and if the political ties directly matters for the firm performance. As we stated in our manuscript, the existing literature commonly suggests that in case of political ties, the cost of obtaining and cultivating political connections may outweigh the benefits obtained through such affairs. Besides, the effect of political ties may change in different economies and environments. That is why the direct effect of political ties on firm performance becomes an important empirical question, as previous studies have shown that the political ties are critical not only for firm performance but also for their survival in the emerging economies setting (Sheng et. al., 2011; Yeniaras et al., 2020).

Third, supporting the extant literature (Chen et al., 2018; Forkmann et al., 2018; Liu et al., 2018; Sheng et al., 2011), our study shows that the relationships among business/political ties, organizational unlearning, exploratory/exploitative innovation and firm performance may act as an alternate mechanism that elucidates the positive links of business ties and the negative connections of political ties to both financial and non-financial firm performance. Drawing simultaneously from relational governance and dynamic capabilities theories, we suggest that business ties may enable firms to seize opportunities, evade threats and obtain competitiveness through regenerative, renewing and incremental dynamic skills, in that order. Nevertheless, political ties seem to restrict firms' ability to cultivate these dynamic competencies, leading to a negative effect on both financial and 
non-financial firm performance. Our theoretical framework and empirical results shed light on the mixed outcomes pertinent to the relationship of business and political ties to firm performance, where some see insignificant connections (Lau et al., 2002), while others imply positive associations ( $\mathrm{Li}$ et al., 2008; Sheng et al., 2011).

\section{Implications}

The literature demonstrates the vital role of personal networks in firm operations and business practices (Chung et al., 2016; Dong et al., 2013; Sheng et al., 2011); however, few studies offer empirical support for it. Our study, which is grounded in relational governance and dynamic capabilities theories, highlights for managers the need to dissect the benefits and costs of business and political ties, which not only affect firms' capabilities but also their financial and non-financial firm performance. Our findings suggest that business connections contribute to the development of regenerative, renewing and incremental dynamic competencies, thereby indirectly and positively influencing firm performance. Conversely, we establish evidence that political ties hinder these constructs. Hence, an immediate managerial recommendation is the need to recognize and evaluate the potential undesirable impacts of political ties on cultivating skills and firm performance. While we acknowledge that distancing an enterprise from relationships with political actors may not be easy in emerging economies, one possible way to mitigate the dark side effects of political links could be to rely less on them and use other business and social-based relationships as external resources for fostering competencies. Based on our findings, those who are in the position of managing firms should be cautious about the amount of investment made in these links while using their political and business networks in their organizational talent development processes and ensure that the amount of investment in these bonds does not go excessive. It does not always help to achieve the desired and targeted performance result of the resources allocated to the bonds and the investments made. Cases where previously established links have fallen short may be found in other emerging markets (Sheng et al., 2011; Gu et al., 2008). Finally, based on our theoretical framework and empirical findings, we recommend that managers embrace the significance of organizational unlearning in strategic renewal, particularly as it applies to building renewing and incremental dynamic skills for enhanced firm performance. Even a large multinational firm may suffer from the inability to unlearn. A classic example of a failure to unlearn and relearn is famously the Nokia case. Unlearning has been highlighted as one of the reasons behind Nokia's inability to address the market changes. A managerial insistence that refused to unlearn the previously established processes and routines has famously caused a great loss of market share. Accordingly, SMEs, which suffer from lack of internal and external resources unlike major corporations should be cautious in selecting the informal ties that they should be depending on.

\section{Limitations and further research}

This study is not without limitations, and the results should be approached with caution. First, we identified organizational unlearning (i.e. regenerative) and organizational learning (i.e. renewing and incremental) dynamic competencies as serial mediators that explain the relationships of both business and political ties to non-financial and financial firm performance. That said, other dynamic skills may also explain managerial informal ties to firm performance in general. Second, and just as importantly, while the literature mostly uses self-reported subjective firm performance measures in this particular domain (Sheng et al., 2011), the use of objective performance measures might improve empirical robustness. A third limitation relates to our crosssectional data, which we collected from firms that were still in operation. We were unable to track individual firms across their full lifespans based on Ward's (1987) methodology. Fourth, our sample is limited to SMEs that are active in a single emerging economy, Turkey. While emerging economies might share common individualities in terms of their institutional market circumstances, individual cultural factors could vary and result in different pros and cons of managerial informal ties. A fifth limitation involves the lack of moderating variables that could affect the conceptual model that we have empirically tested. Finally, a sectoral analysis of the effect of business and political ties to innovation capabilities and firm performance is critical. This study, because of resource and data limitations, has failed to offer such inferences. Future research may expand on this much needed area. In sum, though, our study provides a starting point grounded in the study of relational governance and dynamic capabilities, leaving opportunities for more extensive research in the future.

\section{References}

Abell, P., Felin, T. and Foss, N. (2008), "Building microfoundations for the routines, capabilities, and performance links", Managerial and Decision Economics, Vol. 29 No. 6, pp. 489-502.

Abernathy, W.J. and Clark, K.B. (1985), "Innovation: mapping the winds of creative destruction", Research Policy, Vol. 14 No. 1, pp. 3-22.

Abraham, R., Aier, S. and Winter, R. (2012), "Two speeds of EAM - a dynamic capabilities perspective", in Aier, S., Ekstedt, M., Matthes, F., Proper, E. and Sanz, J.L. (Eds) Trends in Enterprise Architecture Research and Practice-Driven Research on Enterprise Transformation, Springer, Berlin, Heidelberg, 111-128.

Adler, P.S. and Kwon, S.W. (2002), "Social capital: prospects for a new concept", Academy of Management Review, Vol. 27 No. 1, pp. 17-40.

Agarwal, R. and Helfat, C.E. (2009), "Strategic renewal of organizations”, Organization Science, Vol. 20 No. 2, pp. 281-293.

Akgün, A.E., Keskin, H., Byrne, J.C. and Aren, S. (2007), "Emotional and learning capability and their impact on product innovativeness and firm performance", Technovation, Vol. 27 No. 9, pp. 501-513.

Alimadadi, S. and Pahlberg, C. (2014), "A network view of MNC embeddedness in a politically uncertain market: the case of Turkey", Business and Politics, Vol. 16 No. 2, pp. 339-372.

Ambrosini, V. and Bowman, C. (2009), "What are dynamic capabilities and are they a useful construct in strategic management?", International fournal of Management Reviews, Vol. 11 No. 1, pp. 29-49.

Anderson, P. (1999), "Perspective: complexity theory and organization science", Organization Science, Vol. 10 No. 3, pp. 216-232. 
Ang, S.H. (2008), "Competitive intensity and collaboration: impact on firm growth across technological environments", Strategic Management fournal, Vol. 29 No. 10, pp. 1057-1075.

Atasoy, Y. (2009), "Islam's marriage with neoliberalism", Islam's Marriage with Neoliberalism, Palgrave Macmillan, London, pp. 1-31.

Atuahene-Gima, K. and Murray, J.Y. (2007), "Exploratory and exploitative learning in new product development: a social capital perspective on new technology ventures in China", Fournal of International Marketing, Vol. 15 No. 2, pp. 1-29.

Atuahene-Gima, K., Slater, S.F. and Olson, E.M. (2005), "The contingent value of responsive and proactive market orientations for new product program performance", fournal of Product Innovation Management, Vol. 22 No. 6, pp. 464-482.

Auh, S. and Menguc, B. (2005), "Balancing exploration and exploitation: the moderating role of competitive intensity", Fournal of Business Research, Vol. 58 No. 12, pp. 1652-1661.

Bain, J. (1968), Industrial Organization, Wiley, New York, NY.

Barreto, I. (2010), "Dynamic capabilities: a review of past research and an agenda for the future", fournal of Management, Vol. 36 No. 1, pp. 256-280.

Becker, K. (2008), "Unlearning as a driver of sustainable change and innovation: three Australian case studies", International Fournal of Technology Management, Vol. 42 Nos 1/2, pp. 89-106.

Becker, K. (2010), "Facilitating unlearning during implementation of new technology", fournal of Organizational Change Management, Vol. 23 No. 3, pp. 251-268.

Belderbos, R., Faems, D., Leten, B. and Looy, B.V. (2010), "Technological activities and their impact on the financial performance of the firm: exploitation and exploration within and between firms", Fournal of Product Innovation Management, Vol. 27 No. 6, pp. 869-882.

Benner, M.J. and Tushman, M. (2002), "Process management and technological innovation: a longitudinal study of the photography and paint industries", Administrative Science Quarterly, Vol. 47 No. 4, pp. 676-707.

Benner, M.J. and Tushman, M.L. (2003), "Exploitation, exploration, and process management: the productivity dilemma revisited", Academy of Management Review, Vol. 28 No. 2, pp. 238-256.

Bernheim, B.D. and Whinston, M.D. (1998), "Incomplete contracts and strategic ambiguity", American Economic Review, Vol. 88 No. 4, pp. 902-932.

Bierly, P.E., III. and Daly, P.S. (2007), “Alternative knowledge strategies, competitive environment, and organizational performance in small manufacturing firms", Entrepreneurship Theory and Practice, Vol. 31 No. 4, pp. 493-516.

Bogenrieder, I. (2002), "Social architecture as a prerequisite for organizational learning", Management Learning, Vol. 33 No. 2, pp. 197-212.

Broekhuizen, T.L., Giarratana, M.S. and Torres, A. (2017), "Uncertainty avoidance and the exploration-exploitation trade-off”, European fournal of Marketing, Vol. 51 Nos 11/12, pp. 2080-2100.

Brozovic, D. (2018), "Strategic flexibility: a review of the literature", International fournal of Management Reviews, Vol. 20 No. 1, pp. 3-31.

Cannon, J.P. and Perreault, W.D. Jr(1999), "Buyer-seller relationships in business markets", fournal of Marketing Research, Vol. 36 No. 4, pp. 439-460.
Casillas, J.C., Acedo, F.J. and Barbero, J.L. (2010), "Learning, unlearning and internationalisation: evidence from the preexport phase", International fournal of Information Management, Vol. 30 No. 2, pp. 162-173.

Cegarra-Navarro, J.G. and Cepeda-Carrión, G. (2013), "Implementing telemedicine technologies through an unlearning context in a homecare setting", Behaviour \& Information Technology, Vol. 32 No. 1, pp. 80-90.

Cegarra-Navarro, J.G. and Sánchez-Polo, M.T. (2008), "Linking the individual forgetting context with customer capital from a seller's perspective", fournal of the Operational Research Society, Vol. 59 No. 12, pp. 1614-1623.

Cegarra-Navarro, J.G., Sánchez-Vidal, M.E. and CegarraLeiva, D. (2011), "Balancing exploration and exploitation of knowledge through an unlearning context", Management Decision, Vol. 49 No. 7, pp. 1099-1119.

Cegarra-Navarro, J.G., Soto-Acosta, P. and Wensley, A.K. (2016), "Structured knowledge processes and firm performance: the role of organizational agility", fournal of Business Research, Vol. 69 No. 5, pp. 1544-1549.

Cegarra-Navarro, J.G., Martinez-Martinez, A., Ortega-Gutiérrez, J. and Leal-Rodríguez, A.L. (2013), "Environmental knowledge, unlearning, and performance in hospitality companies", Management Decision, Vol. 51 No. 2, pp. 341-360.

Cepeda-Carrión, G., Gabriel Cegarra-Navarro, J. and LealMillán, A.G. (2012), "Finding the hospital-in-the-home units' innovativeness", Management Decision, Vol. 50 No. 9, pp. 1596-1617.

Chang, A. and Tseng, C.N. (2005), "Building customer capital through relationship marketing activities: the case of Taiwanese multilevel marketing companies", fournal of Intellectual Capital, Vol. 6 No. 2, pp. 253-266.

Chen, M., Liu, H., Wei, S. and Gu, J. (2018), “Top managers' managerial ties, supply chain integration, and firm performance in China: a social capital perspective", Industrial Marketing Management, Vol. 74, pp. 205-214.

Chetty, S.K. and Stangl, L.M. (2010), "Internationalization and innovation in a network relationship context", European Fournal of Marketing, Vol. 44 Nos 11/12, pp. 1725-1743.

Child, J. and Tse, D. (2001), "China's transition and its implications for international business", Fournal of International Business Studies, Vol. 32 No. 1, pp. 5-21.

Chung, H.F. (2011), "Market orientation, guanxi, and business performance", Industrial Marketing Management, Vol. 40 No. 4, pp. 522-533.

Chung, H.F. (2012), "Export market orientation, managerial ties, and performance", International Marketing Review, Vol. 29 No. 4, pp. 403-423.

Chung, H.F. and Kuo, T. (2018), "When and how managerial ties matter in international competitive strategy, export financial and strategic performance framework: a standardized or customized approach? ", European fournal of Marketing, Vol. 52 Nos 1/2, pp. 260-278.

Chung, H.F., Wang, C.L., Huang, P.H. and Yang, Z. (2016), "Organizational capabilities and business performance: when and how does the dark side of managerial ties matter?", Industrial Marketing Management, Vol. 55, pp. 70-82.

Collinson, S. and Wilson, D.C. (2006), "Inertia in Japanese organizations: knowledge management routines and failure to innovate", Organization Studies, Vol. 27 No. 9, pp. 1359-1387. 
Crossan, M.M. and Berdrow, I. (2003), "Organizational learning and strategic renewal", Strategic Management fournal, Vol. 24 No. 11, pp. 1087-1105.

Crossan, M.M., Lane, H.W. and White, R.E. (1999), "An organizational learning framework: from intuition to institution", Academy of Management Review, Vol. 24 No. 3, pp. 522-537.

Cummings, J.L. and Teng, B.S. (2003), "Transferring R\&D knowledge: the key factors affecting knowledge transfer success", Fournal of Engineering and Technology Management, Vol. 20 No. 1-2, pp. 39-68.

Danneels, E. (2002), "The dynamics of product innovation and firm competences", Strategic Management fournal, Vol. 23 No. 12, pp. 1095-1121.

Dayan, M., Zacca, R., Husain, Z., Benedetto, A.D. and Ryan, J.C. (2016), "The effect of entrepreneurial orientation, willingness to change, and development culture on new product exploration in small enterprises", fournal of Business E Industrial Marketing, Vol. 31 No. 5, pp. 668-683.

De Geus, A.P. (1988), "Planning as learning", Harvard Business Review, pp. 70-74.

De Holan, P.M. and Phillips, N. (2011), "Organizational forgetting", in Easterby-Smith, M. and Lyles, M.A. (Eds) Handbook of Organizational Learning and Knowledge Management, John Wiley, Hoboken, NJ, pp. 433-452.

de Holan, P.M., Phillips, N. and Lawrence, T.B. (2004), "Managing organizational forgetting", MIT Sloan Management Review, Vol. 45 No. 2, p. 45.

Diamantopoulos, A. and Winklhofer, H.M. (2001), "Index construction with formative indicators: an alternative to scale development”, fournal of Marketing Research, Vol. 38 No. 2, pp. 269-277.

Dong, M.C., Li, C.B. and Tse, D.K. (2013), "Do business and political ties differ in cultivating marketing channels for foreign and local firms in China?", fournal of International Marketing, Vol. 21 No. 1, pp. 39-56.

Dubini, P. and Aldrich, H. (1991), "Personal and extended networks are central to the entrepreneurial process", fournal of Business Venturing, Vol. 6 No. 5, pp. 305-313.

Duffy, J. (2000), "Measuring customer capital", Strategy \& Leadership, Vol. 28 No. 5, pp. 10-15.

Dyer, J.H. and Singh, H. (1998), "The relational view: cooperative strategy and sources of interorganizational competitive advantage", Academy of Management Review, Vol. 23 No. 4, pp. 660-679.

Eisenhardt, K.M. and Martin, J.A. (2000), "Dynamic capabilities: what are they? ", Strategic Management fournal, Vol. 21 Nos 10/11, pp. 1105-1121.

Evanschitzky, H., Eisend, M., Calantone, R.J. and Jiang, Y. (2012), "Success factors of product innovation: an updated meta-analysis", Fournal of Product Innovation Management, Vol. 29, pp. 21-37.

Felin, T. and Hesterly, W.S. (2007), "The knowledge-based view, nested heterogeneity, and new value creation: philosophical considerations on the locus of knowledge", Academy of Management Review, Vol. 32 No. 1, pp. 195-218.

Fernández-Pérez, V., Verdu-Jover, A.J. and Benitez-Amado, J. (2013), "Managerial social networks and strategic flexibility: the role of strategic orientation", Personnel Review, Vol. 42 No. 2, pp. 134-153.
Forkmann, S., Henneberg, S.C. and Mitrega, M. (2018), "Capabilities in business relationships and networks: research recommendations and directions", Industrial Marketing Management, Vol. 74, pp. 4-26.

Fornell, C. and Larcker, D.F. (1981), "Structural equation models with unobservable variables and measurement error: Algebra and statistics", fournal of Marketing Research, Vol. 18 No. 3, pp. 382-388.

Gao, Y., Shu, C., Jiang, X., Gao, S. and Page, A.L. (2017), "Managerial ties and product innovation: the moderating roles of macro-and micro-institutional environments", Long Range Planning, Vol. 50 No. 2, pp. 168-183.

Gavetti, G. and Rivkin, J.W. (2007), "On the origin of strategy: action and cognition over time", Organization Science, Vol. 18 No. 3, pp. 420-439.

Ghoshal, S. and Moran, P. (1996), "Bad for practice: a critique of the transaction cost theory", Academy of Management Review, Vol. 21 No. 1, pp. 13-47.

Gibbons, D.E. (2004), "Friendship and advice networks in the context of changing professional values", Administrative Science Quarterly, Vol. 49 No. 2, pp. 238-262.

Gilbert, C.G. (2005), "Unbundling the structure of inertia: resource versus routine rigidity", Academy of Management Fournal, Vol. 48 No. 5, pp. 741-763.

Gilsing, V., Nooteboom, B., Vanhaverbeke, W., Duysters, G. and van den Oord, A. (2008), "Network embeddedness and the exploration of novel technologies: technological distance, betweenness centrality and density", Research Policy, Vol. 37 No. 10, pp. 1717-1731.

Glazer, R. and Weiss, A.M. (1993), "Marketing in turbulent environments: decision processes and the time-sensitivity of information", fournal of Marketing Research, Vol. 30 No. 4, pp. 509-521.

Goldman, E., Rocholl, J. and So, J. (2013), "Politically connected boards of directors and the allocation of procurement contracts”, Review of Finance, Vol. 17 No. 5, pp. 1617-1648.

Grant, R.M. (1991), "The resource-based theory of competitive advantage: implications for strategy formulation", California Management Review, Vol. 33 No. 3, pp. 114-135.

Gu, F.F., Hung, K. and Tse, D.K. (2008), "When does guanxi matter? Issues of capitalization and its dark sides", fournal of Marketing, Vol. 72 No. 4, pp. 12-28.

Gupta, A.K., Smith, K.G. and Shalley, C.E. (2006), "The interplay between exploration and exploitation", Academy of Management fournal, Vol. 49 No. 4, pp. 693-706.

Hagedoorn, J. and Frankort, H.T. (2008), "The gloomy side of embeddedness: the effects of overembeddedness on interfirm partnership formation", Advances in Strategic Management, Vol. 25, pp. 503-530.

Hair, J.F., Hult, G.T.M., Ringle, C. and Sarstedt, M. (2013), A Primer on Partial Least Squares Structural Equation Modeling (PLS-SEM), 2nd ed., Sage Publications, Thousand Oaks, CA.

Hair, J.F., Sarstedt, M., Pieper, T.M. and Ringle, C.M. (2012), "The use of partial least squares structural equation modeling in strategic management research: a review of past practices and recommendations for future applications", Long Range Planning, Vol. 45 Nos 5/6, pp. 320-340.

Hair, J.F., Black, W.C., Babin, B.J., Anderson, R.E. and Tatham, R.L. (1998), Multivariate Data Analysis, Vol. 5 No. 3, Prentice Hall, Upper Saddle River, NJ, pp. 207-219. 
Harel, O., Zimmerman, R. and Dekhtyar, O. (2008), "Approaches to the handling of missing data in communication research", in Hayes, A.F., Slater, M.D. and Snyder, L.B. (Eds), The SAGE Sourcebook of Advanced Data Analysis Methods for Communication Research, Sage Publications, Los Angeles, CA, pp. 349-371.

Hayes, J.A. (2012), "PROCESS: a versatile computational tool for observed variable mediation, moderation, and conditional process modeling", White paper, available at: www.afhayes.com/public/process2012.pdf

Hedberg, B. (1981), "How organizations learn and unlearn", in Nystrom, P.C. and Starbuck, W.H. (Eds), Handbook of Organizational Design, Oxford University Press, Oxford, Vol. 1, pp. 3-27.

Heirati, N. and O'Cass, A. (2016), “Supporting new product commercialization through managerial social ties and market knowledge development in an emerging economy", Asia Pacific Fournal of Management, Vol. 33 No. 2, pp. 411-433.

Helfat, C.E., Finkelstein, S., Mitchell, W., Peteraf, M.A., Singh, H., Teece, D.J. and Winter, S.G. (2007), Dynamic Capabilities: Understanding Strategic Change in Organizations, Malden, MA: Blackwell.

Helfat, C.E. and Peteraf, M.A. (2003), "The dynamic resource-based view: capability lifecycles", Strategic Management fournal, Vol. 24 No. 10, pp. 997-1010.

Henseler, J., Ringle, C.M. and Sarstedt, M. (2015), "A new criterion for assessing discriminant validity in variance-based structural equation modeling", Fournal of the Academy of Marketing Science, Vol. 43 No. 1, pp. 115-135.

Hooley, G.J., Lynch, J.E. and Jobber, D. (1992), “Generic marketing strategies", International fournal of Research in Marketing, Vol. 9 No. 1, pp. 75-89.

Huff, J.O., Huff, A.S. and Thomas, H. (1992), "Strategic renewal and the interaction of cumulative stress and inertia", Strategic Management fournal, Vol. 13, pp. 55-75.

Hunt, S.D. (1997), "Resource-advantage theory: an evolutionary theory of competitive firm behavior?", Fournal of Economic Issues, Vol. 31 No. 1, pp. 59-78.

Iriyama, A., Kishore, R. and Talukdar, D. (2016), "Playing dirty or building capability? Corruption and HR training as competitive actions to threats from informal and foreign firm rivals", Strategic Management fournal, Vol. 37 No. 10, pp. 2152-2173.

James, L.R., Demaree, R.G. and Wolf, G. (1984), "Estimating within-group interrater reliability with and without response bias", fournal of Applied Psychology, Vol. 69 No. 1, p. 85.

Jansen, J.J., Van Den Bosch, F.A. and Volberda, H.W. (2006), "Exploratory innovation, exploitative innovation, and performance: effects of organizational antecedents and environmental moderators", Management Science, Vol. 52 No. 11, pp. 1661-1674.

Janssen, M.A., Schoon, M.L., Ke, W. and Börner, K. (2006), "Scholarly networks on resilience, vulnerability and adaptation within the human dimensions of global environmental change", Global Environmental Change, Vol. 16 No. 3, pp. 240-252.

Jarvis, C.B., MacKenzie, S.B. and Podsakoff, P.M. (2003), "A critical review of construct indicators and measurement model misspecification in marketing and consumer research", fournal of Consumer Research, Vol. 30 No. 2, pp. 199-218.

Jaworski, B.J. and Kohli, A.K. (1993), "Market orientation: antecedents and consequences", fournal of Marketing, Vol. 57 No. 3, pp. 53-70.

Jiménez-Jiménez, D. and Sanz-Valle, R. (2011), "Innovation, organizational learning, and performance", fournal of Business Research, Vol. 64 No. 4, pp. 408-417.

Jin, L.J., Zhou, K.Z. and Wang, Y. (2016), "Exploitation and exploration in international joint ventures: moderating effects of partner control imbalance and product similarity", Fournal of International Marketing, Vol. 24 No. 4, pp. 20-38.

Johnson, J. and Tellis, G.J. (2008), "Drivers of success for market entry into China and India", fournal of Marketing, Vol. 72 No. 3, pp. 1-13.

Joshi, A.W. and Sharma, S. (2004), "Customer knowledge development: antecedents and impact on new product performance", Fournal of Marketing, Vol. 68 No. 4, pp. 47-59.

Kaya, I. and Kaya, O. (2019), "Foreign aid, institutional quality and government fiscal behavior in emerging economies: an empirical investigation", The Quarterly Review of Economics and Finance, Vol. 76, doi: 10.1016/j.qref.2019.08.004.

Kennerley, M. and Neely, A. (2003), "Measuring performance in a changing business environment", International fournal of Operations \& Production Management, Vol. 23 No. 2, pp. 213-229.

Kim, N. and Atuahene-Gima, K. (2010), "Using exploratory and exploitative market learning for new product development", Fournal of Product Innovation Management, Vol. 27 No. 4, pp. 519-536.

Kock, N. and Lynn, G. (2012), "Lateral collinearity and misleading results in variance-based SEM: an illustration and recommendations", fournal of the Association for Information Systems, Vol. 13 No. 7, pp. 546-580.

Kollmann, T. and Stöckmann, C. (2014), "Filling the entrepreneurial orientation-performance gap: the mediating effects of exploratory and exploitative innovations", Entrepreneurship Theory and Practice, Vol. 38 No. 5, pp. 1001-1026.

Kraft, P.S. and Bausch, A. (2018), "Managerial social networks and innovation: a meta-analysis of bonding and bridging effects across institutional environments", fournal of Product Innovation Management, Vol. 35 No. 6, pp. 865-889.

Lant, T.K., Milliken, F.J. and Batra, B. (1992), "The role of managerial learning and interpretation in strategic persistence and reorientation: an empirical exploration", Strategic Management fournal, Vol. 13 No. 8, pp. 585-608.

Lau, C.M., David, K.T. and Zhou, N. (2002), "Institutional forces and organizational culture in China: effects on change schemas, firm commitment and job satisfaction", fournal of International Business Studies, Vol. 33 No. 3, pp. 533-550.

Leal-Rodríguez, A.L., Eldridge, S., Roldán, J.L., Leal-Millán, A.G. and Ortega-Gutiérrez, J. (2015), “Organizational unlearning, innovation outcomes, and performance: the moderating effect of firm size", Fournal of Business Research, Vol. 68 No. 4, pp. 803-809.

Lechner, C. and Floyd, S.W. (2012), "Group influence activities and the performance of strategic initiatives", Strategic Management fournal, Vol. 33 No. 5, pp. 478-495. 
Levinthal, D. and March, J.G. (1981), "A model of adaptive organizational search", Fournal of Economic Behavior $\mathcal{E}$ Organization, Vol. 2 No. 4, pp. 307-333.

Levinthal, D.A. and March, J.G. (1993), "The myopia of learning", Strategic Management fournal, Vol. 14, pp. 95-112.

Lewin, K. (1951), Field Theory in Social Science, Harper, New York, NY.

Li, J.J. and Sheng, S. (2011), "When does guanxi bolster or damage firm profitability? The contingent effects of firm-and market-level characteristics", Industrial Marketing Management, Vol. 40 No. 4, pp. 561-568.

Li, H. and Zhang, Y. (2007), "The role of managers' political networking and functional experience in new venture performance: evidence from China's transition economy", Strategic Management fournal, Vol. 28 No. 8, pp. 791-804.

Li, J.J., Poppo, L. and Zhou, K.Z. (2008), "Do managerial ties in China always produce value? Competition, uncertainty, and domestic vs foreign firms", Strategic Management Fournal, Vol. 29 No. 4, pp. 383-400.

Li, J.J., Zhou, K.Z. and Shao, A.T. (2009), "Competitive position, managerial ties, and profitability of foreign firms in China: an interactive perspective", fournal of International Business Studies, Vol. 40 No. 2, pp. 339-352.

Liu, H., Yang, J.Y. and Augustine, D. (2018), "Political ties and firm performance: the effects of proself and prosocial engagement and institutional development", Global Strategy fournal, Vol. 8 No. 3, pp. 471-502.

Lubatkin, M.H., Simsek, Z., Ling, Y. and Veiga, J.F. (2006), "Ambidexterity and performance in small-to medium-sized firms: the pivotal role of top management team behavioral integration", fournal of Management, Vol. 32 No. 5, pp. 646-672.

Luo, Y. and Chen, M. (1997), "Does guanxi influence firm performance?", Asia Pacific fournal of Management, Vol. 14 No. 1, pp. 1-16.

McGill, M.E. and Slocum, J.W. Jr (1993), "Unlearning the organization”, Organizational Dynamics, Vol. 22 No. 2, pp. 67-79.

Macneil, I.R. (1980), "Economic analysis of contractual relations: its shortfalls and the need for a rich classificatory apparatus", Northwestern University Law Review, Vol. 75, p. 1018.

March, J.G. (1991), "Exploration and exploitation in organizational learning”, Organization Science, Vol. 2 No. 1, pp. 71-87.

Megill, K. (1997), The Corporate Memory: Information Management in the Electronic Age, London: Bowker Saur.

Menguc, B., Auh, S. and Wang, F. (2020), "Customer participation variation and its impact on customer service performance: underlying process and boundary conditions", Fournal of Service Research, Vol. 23 No. 3, p. 1094670519899161.

Morgan, R.E. and Berthon, P. (2008), "Market orientation, generative learning, innovation strategy and business performance inter-relationships in bioscience firms", fournal of Management Studies, Vol. 45 No. 8, pp. 1329-1353.

Morgan, R.M. and Hunt, S.D. (1994), "The commitmenttrust theory of relationship marketing", fournal of Marketing, Vol. 58 No. 3, pp. 20-38.

Myers, T.A. (2011), “Goodbye, listwise deletion: presenting hot deck imputation as an easy and effective tool for handling missing data", Communication Methods and Measures, Vol. 5 No. 4, pp. 297-310.
Navarro, J.G.C. and Moya, B.R. (2005), "Business performance management and unlearning process", Knowledge and Process Management, Vol. 12 No. 3, pp. 161-170.

Nunnally, J.C. (1978), Psychometric Theory, 2nd ed., McGrawHill, Hillsdale, NJ.

O'Cass, A., Heirati, N. and Ngo, L.V. (2014), "Achieving new product success via the synchronization of exploration and exploitation across multiple levels and functional areas", Industrial Marketing Management, Vol. 43 No. 5, pp. 862-872.

Özcan, G.B. and Gündüz, U. (2015), "Political connectedness and business performance: evidence from Turkish industry rankings”, Business and Politics, Vol. 17 No. 1, pp. 41-73.

Peng, M.W. and Luo, Y. (2000), "Managerial ties and firm performance in a transition economy: the nature of a micromacro link", Academy of Management fournal, Vol. 43 No. 3, pp. 486-501.

Piao, M. and Zajac, E.J. (2016), "How exploitation impedes and impels exploration: theory and evidence", Strategic Management fournal, Vol. 37 No. 7, pp. 1431-1447.

Poppo, L. and Zenger, T. (2002), "Do formal contracts and relational governance function as substitutes or complements? ", Strategic Management fournal, Vol. 23 No. 8, pp. 707-725.

Porter, M.E. (1996), "What is strategy?", Harvard Business Review, Vol. 74 No. 6, pp. 61-78.

Raisch, S. and Birkinshaw, J. (2008), "Organizational ambidexterity: antecedents, outcomes, and moderators", Fournal of Management, Vol. 34 No. 3, pp. 375-409.

Rampersad, H.K. (2004), "Learning and unlearning in accordance with organizational change", Organization Development fournal, Vol. 22 No. 4, pp. 43-60.

Ringle, C.M., Wende, S. and Becker, J.M. (2015), SmartPLS 3. Technical report, SmartPLS GmbH, Boenningstedt, available at: www.smartpls.com

Rodan, S. and Galunic, C. (2004), "More than network structure: how knowledge heterogeneity influences managerial performance and innovativeness", Strategic Management fournal, Vol. 25 No. 6, pp. 541-562.

Salvato, C. (2009), "Capabilities unveiled: the role of ordinary activities in the evolution of product development processes", Organization Science, Vol. 20 No. 2, pp. 384-409.

Sanz-Valle, R., Naranjo-Valencia, J.C., Jiménez-Jiménez, D. and Perez-Caballero, L. (2011), "Linking organizational learning with technical innovation and organizational culture", fournal of Knowledge Management, Vol. 15 No. 6, pp. 997-1015.

Sarstedt, M., Ringle, C.M., Smith, D., Reams, R. and Hair, J. F. Jr (2014), "Partial least squares structural equation modeling (PLS-SEM): a useful tool for family business researchers", Fournal of Family Business Strategy, Vol. 5 No. 1, pp. 105-115.

Schiffer, M. and Weder, B. (2001), Firm Size and the Business Environment: Worldwide Survey Results, World Bank Publications, Washington, DC.

Schmitt, A., Barker, V.L., III, Raisch, S. and Whetten, D. (2016), "Strategic renewal in times of environmental scarcity”, Long Range Planning, Vol. 49 No. 3, pp. 361-376.

Schmitt, A., Raisch, S. and Volberda, H.W. (2018), "Strategic renewal: past research, theoretical tensions and future 
challenges", International fournal of Management Reviews, Vol. 20 No. 1, pp. 81-98.

Senge, P. (1990), The Fifth Discipline: The Art and Practice of the Learning Organization, Doubleday, New York, NY.

Sheng, S., Zhou, K.Z. and Li, J.J. (2011), "The effects of business and political ties on firm performance: evidence from China", Fournal of Marketing, Vol. 75 No. 1, pp. 1-15.

Sheth, J.N. (2011), "Impact of emerging markets on marketing: rethinking existing perspectives and practices", Fournal of Marketing, Vol. 75 No. 4, pp. 166-182.

Shu, C., Page, A.L., Gao, S. and Jiang, X. (2012), "Managerial ties and firm innovation: is knowledge creation a missing link?", fournal of Product Innovation Management, Vol. 29 No. 1, pp. 125-143.

Sinkula, J. (2002), "Market-based success, organizational routines, and unlearning”, fournal of Business E Industrial Marketing, Vol. 17 No. 4, pp. 253-269.

Smith, W.K. and Tushman, M.L. (2005), "Managing strategic contradictions: a top management model for managing innovation streams", Organization Science, Vol. 16 No. 5, pp. 522-536.

Sørensen, J.B. and Stuart, T.E. (2000), “Aging, obsolescence, and organizational innovation", Administrative Science Quarterly, Vol. 45 No. 1, pp. 81-112.

Sparrowe, R.T. and Liden, R.C. (2005), "Two routes to influence: integrating leader-member exchange and social network perspectives", Administrative Science Quarterly, Vol. 50 No. 4, pp. 505-535.

Starbuck, W.H. (1996), "Unlearning ineffective or obsolete technologies", International fournal of Technology Management, Vol. 11 No. 7, pp. 725-737.

Stopford, J.M. and Baden-Fuller, C.W. (1994), "Creating corporate entrepreneurship", Strategic Management fournal, Vol. 15 No. 7, pp. 521-536.

Story, V.M., Boso, N. and Cadogan, J.W. (2015), "The form of relationship between firm-level product innovativeness and new product performance in developed and emerging markets", fournal of Product Innovation Management, Vol. 32 No. 1, pp. 45-64.

$\mathrm{Su}, \mathrm{Z}$. and Yang, H. (2018), "Managerial ties and exploratory innovation: an opportunity-motivation-ability perspective", IEEE Transactions on Engineering Management, Vol. 65 No. 2, pp. 227-238.

Swift, P.E. and Hwang, A. (2008), "Learning, dynamic capabilities and operating routines: a consumer package goods company", The Learning Organization, Vol. 15 No. 1, pp. 75-95.

Teece, D.J. (2007), "Explicating dynamic capabilities: the nature and microfoundations of (sustainable) enterprise performance", Strategic Management Fournal, Vol. 28 No. 13, pp. 1319-1350.

Thornton, S.C., Henneberg, S.C. and Naudé, P. (2014), "Conceptualizing and validating organizational networking as a second-order formative construct", Industrial Marketing Management, Vol. 43 No. 6, pp. 951-966.

Tsang, E.W. and Zahra, S.A. (2008), "Organizational unlearning”, Human Relations, Vol. 61 No. 10, pp. 1435-1462.

Vera, D. and Crossan, M. (2004), "Strategic leadership and organizational learning”, Academy of Management Review, Vol. 29 No. 2, pp. 222-240.
Vera, D., Nemanich, L., Vélez-Castrillón, S. and Werner, S. (2016), "Knowledge-based and contextual factors associated with R\&D teams' improvisation capability”, fournal of Management, Vol. 42 No. 7, pp. 1874-1903.

Wang, C.L. and Ahmed, P.K. (2007), "Dynamic capabilities: a review and research agenda", International Fournal of Management Reviews, Vol. 9 No. 1, pp. 31-51.

Wang, X., Qi, Y. and Zhao, Y. (2019), "Individual unlearning, organizational unlearning and strategic flexibility", Baltic Fournal of Management, Vol. 14 No. 1, pp. 2-18.

Wang, G., Jiang, X., Yuan, C.H. and Yi, Y.Q. (2013), "Managerial ties and firm performance in an emerging economy: tests of the mediating and moderating effects", Asia Pacific Fournal of Management, Vol. 30 No. 2, pp. 537-559.

Wang, C., Rodan, S., Fruin, M. and Xu, X. (2014), "Knowledge networks, collaboration networks, and exploratory innovation", Academy of Management fournal, Vol. 57 No. 2, pp. 484-514.

Ward, J. (1987), Keeping the Family Business Healthy, JosseyBass, San Francisco, CA.

Watson, D., Clark, L.A. and Carey, G. (1988), "Positive and negative affectivity and their relation to anxiety and depressive disorders", fournal of Abnormal Psychology, Vol. 97 No. 3, p. 346.

Wilden, R., Gudergan, S.P., Nielsen, B.B. and Lings, I. (2013), "Dynamic capabilities and performance: strategy, structure and environment", Long Range Planning, Vol. 46 No. 1-2, pp. 72-96.

Winter, S.G. (2003), "Understanding dynamic capabilities", Strategic Management fournal, Vol. 24 No. 10, pp. 991-995.

Wu, J. (2011), “Asymmetric roles of business ties and political ties in product innovation", fournal of Business Research, Vol. 64 No. 11, pp. 1151-1156.

Xin, K.K. and Pearce, J.L. (1996), "Guanxi: connections as substitutes for formal institutional support", Academy of Management Foumal, Vol. 39 No. 6, pp. 1641-1658.

Yalcinkaya, G., Calantone, R.J. and Griffith, D.A. (2007), “An examination of exploration and exploitation capabilities: implications for product innovation and market performance", Fournal of International Marketing, Vol. 15 No. 4, pp. 63-93.

Yannopoulos, P., Auh, S. and Menguc, B. (2012), "Achieving fit between learning and market orientation: implications for new product performance", Fournal of Product Innovation Management, Vol. 29 No. 4, pp. 531-545.

Yeniaras, V., Kaya, I. and Ashill, N. (2020), "The effects of social ties on innovation behavior and new product performance: the moderating role of market and institutional environments", Fournal of Business $\mathcal{E}$ Industrial Marketing, Vol. 35 No. 4, pp. 699-719.

Yeniaras, V., Kaya, I. and Dayan, M. (2020), "Mixed effects of business and political ties in planning flexibility: insights from Turkey", Industrial Marketing Management, Vol. 87, pp. 208-224.

Yeniaras, V., Sener, P. and Unver, S. (2017), "Is market learning the missing link between family involvement-firm performance relationship? A resource-based perspective", 
International Entrepreneurship and Management fournal, Vol. 13 No. 2, pp. 575-604.

Yeniaras, V. and Unver, S. (2016), "Revisiting the mediating effect of entrepreneurial behaviour on proactivenessperformance relationship: the role of business ties and competitive intensity", European Management Review, Vol. 13 No. 4, pp. 291-306.

Yildirim, H.S., Akci, Y. and Eksi, I.H. (2013), "The effect of firm characteristics in accessing credit for SMEs", fournal of Financial Services Marketing, Vol. 18 No. 1, pp. 40-52.

Zacca, R., Dayan, M. and Ahrens, T. (2015), "Impact of network capability on small business performance: the mediating role of knowledge creation and EO", Management Decision, Vol. 53 No. 1, pp. 2-23.

Zahra, S.A., Abdelgawad, S.G. and Tsang, E.W. (2011), "Emerging multinationals venturing into developed economies: implications for learning, unlearning, and entrepreneurial capability", Fournal of Management Inquiry, Vol. 20 No. 3, pp. 323-330.

Zhang, J., Tan, J. and Wong, P.K. (2015), "When does investment in political ties improve firm performance? The contingent effect of innovation activities", Asia Pacific fournal of Management, Vol. 32 No. 2, pp. 363-387.

Zhao, Y., Lu, Y. and Wang, X. (2013), "Organizational unlearning and organizational relearning: a dynamic process of knowledge management", Fournal of Knowledge Management, Vol. 17 No. 6, pp. 902-912.

Zhou, K.Z. and Poppo, L. (2010), "Exchange hazards, relational reliability, and contracts in China: the contingent role of legal enforceability", fournal of International Business Studies, Vol. 41 No. 5, pp. 861-881.

Zollo, M. and Winter, S.G. (2002), "Deliberate learning and the evolution of dynamic capabilities", Organization Science, Vol. 13 No. 3, pp. 339-351.

Zou, S. and Cavusgil, S.T. (2002), "The GMS: a broad conceptualization of global marketing strategy and its effect on firm performance", fournal of Marketing, Vol. 66 No. 4, pp. 40-56.

\section{Further reading}

Blindenbach-Driessen, F. and Van den Ende, J. (2014), "The locus of innovation: the effect of a separate innovation unit on exploration, exploitation, and ambidexterity in manufacturing and service firms", Fournal of Product Innovation Management, Vol. 31 No. 5, pp. 1089-1105.

Kemper, J., Schilke, O. and Brettel, M. (2013), "Social capital as a microlevel origin of organizational capabilities", fournal of Product Innovation Management, Vol. 30 No. 3, pp. 589-603.

Leenders, R.T. and Dolfsma, W.A. (2016), "Social networks for innovation and new product development", Fournal of Product Innovation Management, Vol. 33 No. 2, pp. 123-131.

Nelson, R.R. and Winter, S.G. (1982), "The Schumpeterian tradeoff revisited", American Economic Review, Vol. 72 No. 1, pp. 114-132.
Siren, C.A., Kohtamäki, M. and Kuckertz, A. (2012), "Exploration and exploitation strategies, profit performance, and the mediating role of strategic learning: escaping the exploitation trap", Strategic Entrepreneurship fournal, Vol. 6 No. 1, pp. $18-41$.

\section{About the authors}

Volkan Yeniaras is a Faculty at Ozyegin University and recently published scholarly articles in such journals as fournal of the Academy of Marketing Science, Industrial Marketing Management, Fournal of Business and Industrial Marketing, Psychology \& Marketing, European Management Review and Fournal of Economic Psychology among others. His current research interest is in the areas of industrial marketing and innovation and entrepreneurship. Volkan Yeniaras is the corresponding author and can be contacted at: vyeniaras82@gmail.com

Anthony Di Benedetto has twice been named one of the 50 leading research scholars worldwide in Innovation and Technology Management by the International Association of Management of Technology. He was previously named one of the leading scholars worldwide in innovation management in a 2007 article in the fournal of Product Innovation Management, and also in a 2006 article in R\&D Management. He has over 100 refereed academic articles published, in journals including Fournal of Product Innovation Management, Management Science, Strategic Management Fournal, Fournal of International Business Studies, Fournal of Operations Management, Fournal of the Academy of Marketing Science, IEEE Transactions on Engineering Management, Industrial Marketing Management, and elsewhere.

Ilker Kaya recently published scholarly articles in such journals as BA fournal of Macroeconomics, Review of Development Economics, Applied Economics and Emerging Market Review, among others. He has also been awarded the best paper award in International Finance at 2007 annual meetings of Southern Finance Association. He also taught several economics courses at the University of Georgia, USA, before joining AUS. His theoretical and empirical research is concentrated in the areas of economic growth, income inequality, poverty, international trade, international finance and financial liberalization.

Mumin Dayan is a Professor of Marketing in the College of Business and Economics in UAEU. His research explores and examines various aspects of innovation and entrepreneurship including product and technology development, cognitive and social psychology in SMEs and family business and decision-making in teams. His work has been published in such journals as fournal of Product Innovation Management, Research Policy, Industrial Marketing Management, Information and Management, Long Range Planning, Business Strategy and the Environment, IEEE Transactions on Engineering Management. 